\title{
Variability in iron (II) oxidation kinetics across diverse hydrothermal sites on the northern Mid Atlantic Ridge
}

\author{
González-Santana David 1, * , González-Dávila Melchor ${ }^{2}$, Lohan Maeve C. ${ }^{3}$, Artigue Lise ${ }^{4}$, \\ Planquette Helene ${ }^{1}$, Sarthou Geraldine ${ }^{1}$, Tagliabue Alessandro ${ }^{5}$, Santana-Casiano J. Magdalena ${ }^{2}$
}

\author{
1 Univ Brest, CNRS, IRD, Ifremer, LEMAR, F-29280 Plouzane, France \\ 2 Instituto de Oceanografía y Cambio Global, IOCAG, Universidad de Las Palmas de Gran Canaria, Las \\ Palmas de Gran Canaria, Spain \\ ${ }^{3}$ Ocean and Earth Science, University of Southampton, National Oceanography Centre, Southampton \\ SO14 3ZH, United Kingdom \\ 4 LEGOS, University of Toulouse, CNRS, CNES, IRD, UPS, 31400 Toulouse, France \\ ${ }^{5}$ School of Environmental Sciences, University of Liverpool, Liverpool, United Kingdom
}

* Corresponding author : David González-Santana, email address : david.gonzalezsantana@univ-brest.fr

\begin{abstract}
:
One of the recently recognized main sources of iron to the deep ocean inventory is the hydrothermal activity associated with mid-ocean ridges. Little is known about the oxidation kinetics of iron(II) within these environments, especially the dependence on physico-chemical parameters such as temperature $(\mathrm{T}), \mathrm{pH}$, particle size-fractionation and the effect of organic matter.

Following sample collection during the GA13 section cruise, the iron(II) oxidation at six hydrothermal vent sites (Menez Gwen, Lucky Strike, Rainbow, Lost City, Broken Spur and TAG) along the Mid-Atlantic Ridge were investigated, revealing high variability. The $\mathrm{Fe}(\mathrm{II})$ oxidation rate constant analysis from multiple stations at two sites (Rainbow and TAG), revealed that factors, other than $\mathrm{T}$ and $\mathrm{pH}$, controlled the oxidation process. Experiments on the effect of particle size-fractionation and organic matter at different $\mathrm{pH}$ showed that the presence of organic ligands and colloidal size particles delayed the oxidation process, while not affecting the overall $\mathrm{pH}$ dependency.

Extending our analysis to the broader relationship between the $\mathrm{Fe}(\mathrm{II})$ oxidation rate constants across a range of temperatures (between 2 and $25^{\circ} \mathrm{C}$ ) and $\mathrm{pH}$ (between 7 and 8 ) on a set of selected hydrothermal samples allowed us to derive a multiparametric equation to model the iron(II) oxidation rate constants in the ocean. This equation covers a larger range of temperatures than previous published equations, improving its applicability for global biogeochemical models.
\end{abstract}




\section{Highlights}

- Organic ligands and nanoparticles increase the resistance to oxidation. We present an improved multiparametric equation to calculate $\mathrm{Fe}$ (II) oxidation rates. Oxidation rates close to the vent sites are systematically faster than theorized.

Keywords : Fe(II) oxidation kinetics, Fe(II) half-life time, Kinetic equation, Hydrothermal, Mid Atlantic Ridge 
39 It is now well-established that phytoplankton growth is limited by the concentration of

40 dissolved iron ( $\mathrm{Fe}$ ) in up to $30 \%$ of the world oceans (Moore et al., 2013). Iron in the ocean,

41 can be found as both ferric (Fe(III)) and ferrous (Fe(II)) iron, where $99 \%$ of the dissolved

$42 \mathrm{Fe}(\mathrm{III})$ is complexed by organic ligands (Rue and Bruland, 1995). In oxic waters, Fe(II) tends

43 to oxidize to the most thermodynamically stable form, Fe(III), in a period of minutes to hours 
44 (Santana-Casiano et al., 2005). Oxidation of Fe causes the solubility to decrease (Millero et al., 1995), therefore, reducing its bioavailability (Shaked et al., 2005; Morel et al., 2008).

Recently, in the context of the international GEOTRACES program (www.geotraces.org), several studies showed that Fe supplied by hydrothermal activity from mid-ocean ridges can have a substantial impact on Fe distributions at basin scales (Tagliabue et al., 2010; Conway and John, 2014; Resing et al., 2015; Fitzsimmons et al., 2017; Tagliabue et al., 2017). Hydrothermal vent supply of $\mathrm{dFe}$ is required to reproduce deep ocean observations (Tagliabue et al., 2010) could represent up to 11-22\% of the dissolved iron (dFe, filtered by $0.2 \mu \mathrm{m}$ ) present in the deep ocean globally (Bennett et al., 2008), accounting for a similar $\mathrm{dFe}$ flux as continental riverine runoff (Elderfield and Schultz, 1996). Therefore, hydrothermalism acts as an important Fe source in the deep ocean which may affect the global biological carbon pump (Tagliabue et al., 2010; Resing et al., 2015).

The concentration of dissolved Fe(II) (dFe(II)) in the open ocean is very low, between 0.02 and $2 \mathrm{nmol} \mathrm{L} \mathrm{L}^{-1}$, due to its fast oxidation under oxic conditions following the Fenton reaction mechanism (González-Davila et al., 2005; Santana-Casiano et al., 2005). However, specific oceanic regions present $\mathrm{dFe}(\mathrm{II})$ concentrations which are orders of magnitude higher. In marine sediment interstitial waters, concentrations can reach around $300 \mu \mathrm{mol} \mathrm{L}^{-1}$ (de Baar and De Jong, 2001), upwelling systems can increase Fe(II) concentrations up to $50 \mathrm{nmol} \mathrm{L}^{-1}$ 62 (Hong and Kester, 1986), while hydrothermal fluids can contain as much as $25 \mathrm{mmol} \mathrm{L}^{-1}$ of dFe(II) (German and Von Damm, 2004). Water emanating from hydrothermal systems contains high concentrations of Fe(II) amongst other elements (Mottl et al., 1979; Mandernack and Tebo, 1993). Studies conducted at hydrothermal vent sites in different ocean basins have revealed different $\mathrm{Fe}(\mathrm{II})$ oxidation rate constants, with $\mathrm{Fe}(\mathrm{II})$ half-life times varying from 0.5 to $220 \mathrm{~min}$, which has important implications for the dispersion of produced 
Fe-oxide phases (Massoth et al., 1998; Field and Sherrell, 2000; Statham et al., 2005; Wang

et al., 2012; Santana-González et al., 2017; Rouxel et al., 2018). Recently, Gartman and

Findlay (2020) compiled all the available data for Fe(II) half-life from four hydrothermal systems. One site was the TAG vent site in the Atlantic Ocean, while the others were located in the Indian and Pacific Oceans, with Fe(II) half-life estimated using large Fe(II) spikes (500 nmol L ${ }^{-1}$ ) that may affect the role played by different reactive oxygen species (González-

Dávila et al., 2006).

Temperature $(\mathrm{T}), \mathrm{pH}$, and oxygen concentration $\left(\mathrm{O}_{2}\right)$ are the primary variables known to directly affect the Fe(II) oxidation (Stumm and Lee, 1961; Millero et al., 1987; Millero and Sotolongo, 1989; Santana-Casiano et al., 2005). Salinity also affects the Fe(II) oxidation, as reported in previous laboratory experiments (Millero et al., 1987; Santana-Casiano et al., 2005). However, other factors such as changes in the inorganic complexation of $\mathrm{Fe}(\mathrm{II})$ due to the specific ionic composition of the vent fluid, or organic complexation can influence these oxidation rate constants (Rose and Waite, 2003; Statham et al., 2005). Therefore, the oxidation rate constants must be termed "apparent" due to the effect of organic complexation (Voelker and Sulzberger, 1996), as the nature and concentrations of organic ligands vary between samples. Moreover, pyrite nanoparticles formed in hydrothermal vent sites, have been estimated to oxidize more slowly than dissolved Fe(II) (Yücel et al., 2011), showing that particle composition also influences the oxidation rate constants. The first empirical equation describing the $\mathrm{Fe}(\mathrm{II})$ oxidation rate constants in seawater was reported by Millero et al. (1987), and later updated by Santana-Casiano et al. (2005) for nanomolar concentrations. This equation has been included in coupled physical-biogeochemical models in the ocean (OGCBMs) to explore the impact of future climate change on the oxidation of Fe(II) 
ranging from 10 to $25^{\circ} \mathrm{C}$, which leads to discrepancies for the $\mathrm{Fe}(\mathrm{II})$ oxidation rate constants for cold, deep ocean water masses.

94 The aims of this study were to measure the oxidation kinetic constants ( $\left.k^{\prime}\right)$ of $\mathrm{Fe}$ (II) from different hydrothermal vents and to investigate whether the variations of $\mathrm{pH}, \mathrm{T}$ and $\mathrm{S}$ can explain the observed variability, or if other factors such as the presence of particles, colloids or dissolved organic matter (DOM) are significant contributors. This updated version of the equation incorporates a wider range of temperatures, which lowers the error associated with the theoretical Fe(II) oxidation rate constants. Thus, it becomes applicable to the calculation of theoretical Fe(II) oxidation for the deep waters in which hydrothermal systems are

101 typically found.

\section{Methods}

\subsection{Sampling sites and characteristics}

104 Seawater samples were collected during the GA13 section cruise (JC156) along the Mid

105 Atlantic Ridge (MAR) onboard the RRS James Cook. This cruise departed Southampton, UK 106 on December $20^{\text {th }}, 2017$ and arrived into Guadeloupe, France on February $1^{\text {st }}, 2018$.

107 Alongside the large scale ocean section survey, sampling focused on six hydrothermal vent sites along the MAR: Menez Gwen (37 $50^{\prime} \mathrm{N} 31^{\circ} 31^{\prime} \mathrm{W}$; Charlou et al., 2000), Lucky Strike

$109\left(37^{\circ} 17^{\prime} \mathrm{N} 32^{\circ} 16^{\prime} \mathrm{W}\right.$; Charlou et al., 2000), Rainbow (36 $16^{\circ} \mathrm{N} 33^{\circ} 54^{\prime} \mathrm{W}$; Douville et al., 110 2002), Lost City (30 $7^{\circ} \mathrm{N} 42^{\circ} 7^{\prime} \mathrm{W}$; Kelley et al., 2001), Broken Spur (29 ${ }^{\circ} \mathrm{N}$; James et al., 111 1995), and TAG (26N; Gamo et al., 1996) (Fig. 1). These six hydrothermal vent sites

112 represent a wide range of possible hydrothermal conditions due to different underlying 113 geological conditions. Lost City and Menez Gwen are the shallowest sites, with the vent site 114 depths located at 700-720 m and 840-850 m, respectively. The Lucky Strike hydrothermal 
115 field is situated between 1560 and $1730 \mathrm{~m}$ depth. The Rainbow vent site is found at 2270-

$1162280 \mathrm{~m}$, within the average range (2000-3000 m) of oceanic ridge depth (Searle, 2013), while

117 Broken Spur and TAG are deeper hydrothermal systems located at 3100-3300 m and 3670-

$1183700 \mathrm{~m}$, respectively. Chemically, Lost City is an alkaline hydrothermal vent, with $\mathrm{pH}$

119 ranging from 9.0 to 9.8 . The vent fluid is at a lower temperature of $40-75{ }^{\circ} \mathrm{C}$, compared to

$120 \quad 185-365^{\circ} \mathrm{C}$ at the other vent sites and has extremely low concentrations of most trace

121 elements (e.g. Fe below the detection limit compared to $2-24000 \mu \mathrm{mol} \mathrm{\textrm {L } ^ { - 1 }}$ at the other vent sites) (Ludwig et al., 2006; Fouquet et al., 2013). All other hydrothermal vent sites are acidic with $\mathrm{pH}$ lower than 4, and act as important sources of trace metals (Charlou et al., 2000;

124 Douville et al., 2002; Andreani et al., 2014). Geologically, Menez Gwen and Lucky Strike are 125 similar, their basement rocks are mafic, enriched-Mid-Ocean Ridge Basalt (E-MORB, 126 enriched with light rare earth elements, LREE), and present sulfide mounds. Rainbow also 127 presents sulfide mounds, but its basement rock is ultramafic. Further south, the alkaline Lost 128 City is also situated above an ultramafic base with carbonate chimneys. Finally, Broken Spur 129 and TAG have sulfide mounds and basement rocks formed by normal-MORB (N-MORB,

130 LREE depletion) (references within Fouquet et al., 2010).

131 Seawater samples were collected according to the GEOTRACES guidelines

132 (http://www.geotraces.org/images/Cookbook.pdf). Briefly, a titanium rosette fitted with $24 \mathrm{x}$ 10 L trace metal-clean Teflon-coated OTE (Ocean Test Equipment) bottles, a CTD profiler

134 (Sea-bird Scientific), light scattering sensor (PMEL MAPR), and a redox potential sensor 135 (PMEL MAPR), were deployed on a conducting Kevlar wire to collect samples from the 136 water column. Sampling depths were actively chosen from the continuous T, salinity (S), 137 light scattering sensor (https://datasearch.nerc.ac.uk:443/geonetwork/srv/api/records/8ba648f2759d57fbb2246671f8065939)

139 and redox potential readings. 
140 Upon recovery, the OTE bottles were transported into an ISO class 6 clean air van. Unfiltered

141 samples (UF) for Fe(II) oxidation kinetics were immediately transferred into thoroughly

142 rinsed acid-cleaned $250 \mathrm{~mL}$ or $1 \mathrm{~L}$ low-density polyethylene bottles (LDPE; Nalgene)

143 following the GEOTRACES Cookbook (http://www.geotraces.org/images/Cookbook.pdf)

144 and frozen at $-20{ }^{\circ} \mathrm{C}$. Samples remained frozen in a $-20{ }^{\circ} \mathrm{C}$ freezer for one year before their

145 analysis. pH samples were collected in $125 \mathrm{~mL}$ borosilicate bottles and kept in the dark until

146 the time of analysis.

\section{$2.2 \mathrm{pH}$ determination}

$148 \mathrm{pH}$ was measured onboard and during laboratory-based kinetic experiments in the free scale

149 using a Tris buffer solution (Millero, 1986). Onboard $\mathrm{pH}$ samples were kept in the dark,

150 inserted into a $25^{\circ} \mathrm{C}$ water bath, and measured at $25^{\circ} \mathrm{C}$, within less than 1 hour after

151 collection. Laboratory-based kinetic experiments used a Titrino 719 (Metrohm ${ }^{\mathrm{TM}}$ ) which

152 automatically added $0.01 \mathrm{M}$ hydrochloric acid (HCl, PANREAC Hiperpur-plus) in order to

153 keep the $\mathrm{pH}$ constant. The $\mathrm{pH}$ at in situ conditions were computed considering the total

154 alkalinity for an average profile of the area (Key et al., 2015; Olsen et al., 2016). The average

155 profile was obtained from plotting all the available alkalinity data from the studied region

$156\left(20-30^{\circ} \mathrm{N}\right.$ and $\left.40-50^{\circ} \mathrm{W}\right)$. The associated error of the estimate was $\pm 6 \mu \mathrm{mol} \mathrm{kg}{ }^{-1}$. Gray et al.

157 (2011) showed that computed $\mathrm{pH}$ values are relatively insensitive to errors in alkalinity, and

158 that $\mathrm{pH}$ measurements can be used to compute the magnitude and variability of inorganic

159 carbon variables. A fluctuation of $400 \mu \mathrm{mol} \mathrm{kg}{ }^{-1}$ in total alkalinity values (e.g. from 2325 to

$1602725 \mu \mathrm{mol} \mathrm{kg}^{-1}$ ) will change the $\mathrm{pH}$ in +0.005 , which lies within the error of determination

161 for potentiometric pH. The set of constants from Lueker et al. (2000) were used.

162 All the $\mathrm{pH}$ data in the text and in the figures, including kinetics and profile data are expressed

163 in the free scale. 
165 In order to measure the $\mathrm{Fe}(\mathrm{II})$ oxidation rate constants, continuous $\mathrm{Fe}(\mathrm{II})$ concentrations were determined using the FeLume System (Waterville Analytical), with a data point acquisition every $1 \mathrm{~s}$. This direct Flow Injection Analysis system uses luminol (5-amino-2,3-dihydro-1,4phthalazinedione, Sigma-Aldrich) as the reagent (King et al., 1995) which reacts with Fe(II).

169 The sample was continuously aerated with pure air (Carburos Metalicos S.A.). A $0.8 \mathrm{nmol} \mathrm{L}^{-1}$ 170 addition of $\mathrm{Fe}(\mathrm{II})$ (ammonium iron(II) sulfate hexahydrate, Sigma-Aldrich) was introduced into each sample and the $\mathrm{Fe}(\mathrm{II})$ concentration was continuously monitored until the signal had reduced by $70 \%$. This method produces apparent rate constants $\left(k_{a p p}\right)$ because the oxidation rate constant is measured on a $\mathrm{Fe}(\mathrm{II})$ spike rather than on the ambient $\mathrm{Fe}(\mathrm{II})$.

174 Although, the oxidation rate constant is not affected by the initial Fe(II) in solution (Millero et al., 1987; Roy et al., 2008; Roy and Wells, 2011; Santana-González et al., 2018), the equilibrium with the organic ligands and particle surfaces could be affected. Moreover, due to the effects of organic complexation and that the concentrations of the organic ligands in each sample are not constant, the apparent oxidation rate constants are consequently not true constants.

180 Some previous oxidation kinetic studies have found a second-order dependency of the Fe(II) concentration against time (e.g. Statham et al., 2005). However, in oxygen saturated samples a pseudo-first order rate dependency was obtained, where the slope $(\ln ([\mathrm{Fe}(\mathrm{II})]$ against time $)$ represents the pseudo-first order rate constant $k^{\prime}$ (Eq. 1). The linearity remained longer than the half-life time and was thus considered acceptable in all the analyses $\left(\mathrm{R}^{2}=0.983 \pm 0.017\right.$,

$185 \mathrm{n}$ samples $=298$ ). The observed linearity confirms that the equilibrium between the added

$186 \mathrm{Fe}(\mathrm{II})$ with organic ligands and particles is achieved before $30 \mathrm{~s}$ (our first Fe(II)

187 determination time limit). The $k$ ' error associated with these high $\mathrm{R}^{2}$ values was $2 \%$ for in 
situ condition experiments, and $1 \%$ for experiments carried out at $25{ }^{\circ} \mathrm{C}$. The half-life $\left(\mathrm{t}_{1 / 2}\right)$ of

$189 \mathrm{Fe}(\mathrm{II})$ in seawater can be calculated from $k^{\prime}$ (Eq. 1 and 2).

$190 d[F e(I I)] / d t=-k_{a p p}[02][F e(I I)]$

191 In oxygen saturated concentrations, the corresponding pseudo-first order rate constant $k^{\prime}=$

$192 k_{\text {app }}\left[\mathrm{O}_{2}\right]$.

$193 \quad t_{1 / 2}=\ln (2) / k^{\prime}$

194 The minimum energy required to start the oxidation reaction (activation energy, $\mathrm{E}_{\mathrm{a}}, \mathrm{J}_{\mathrm{mol}}^{-1}$ )

195 and the corresponding preexponential or frequency factor (A) were computed from the

196 calculated $k^{\prime}$ using the empirical Arrhenius equation, where $\mathrm{R}$ is the universal gas constant

$197 \quad\left(8.314 \mathrm{~J} \mathrm{~mol}^{-1} \mathrm{~K}^{-1}\right)$ :

$198 \log \left(k^{\prime}\right)=\log (A)-\frac{E_{a}}{R \cdot \ln (10) \cdot T}$

199 Iron (II) blanks were obtained from a $2 \mathrm{~h}$ aerated, magnetically stirred sample which was kept

200 in the dark to achieve the oxidation of Fe(II) (Santana-Casiano et al., 2005). Iron (II) in theses

201 blanks always below the detection limit. Calibration curves ( 0 to $1 \mathrm{nmol} \mathrm{L}-1)$ were produced

202 daily and confirmed linearity in the Fe(II) signal. The detection limit, defined as three times

203 the standard deviation of the blank after being aerated for 10 minutes, was lower than 50

204 pmol L ${ }^{-1}$. Reproducibility was checked by running the same sample three times throughout

205 the day after an addition of $1 \mathrm{nmol} \mathrm{L}^{-1}$ of $\mathrm{Fe}(\mathrm{II})$ with an agreement in concentrations that was

206 better than $\pm 0.1 \mathrm{nmol} \mathrm{L}^{-1}$. Accuracy could not be determined since reference materials

207 currently do not exist. Results are systematically given as $\mathrm{t}_{1 / 2}$ (in $\mathrm{min}$ ), followed by the

208 measured $k^{\prime}\left(\right.$ in $\left.\min ^{-1}\right)$. 
210 Using natural seawater samples, kinetic experiments were carried out under different

211 conditions, with $\mathrm{pH}$ and $\mathrm{T}$ set to in situ conditions (data shown in the supplementary Table

212 S1), and with $\mathrm{pH}$ and $\mathrm{T}$ normalized to constant values, in unfiltered, filtered and filtered and

213 UV-irradiated samples. These later experiments required a high sample volume, limiting the

214 number of experiments.

215 The steps required for the Fe(II) oxidation kinetics determination are as follows. The day

216 before the experiments, three to four frozen samples were taken out of the freezer and placed

217 in a fridge set to $4{ }^{\circ} \mathrm{C}$. The next morning, a temperature-controlled water bath was set to the

218 coldest in situ potential temperature (supplementary Table S1). While the water bath was

219 cooling down, each sample was subsampled into three $60 \mathrm{~mL}$ acid cleaned LDPE bottles and

220 placed back into the fridge. One of the subsamples was inserted into the temperature-

221 controlled water bath, which was set to the original in situ potential temperature of the sample. The sample was left in the water bath for acclimatization during $15 \mathrm{~min}$ and then transferred into the reaction vessel. In the reaction vessel, the sample was aerated prior to and

224 during the study. After 10 minutes of aeration, the $\mathrm{Fe}(\mathrm{II})$ addition was made and the $\mathrm{Fe}(\mathrm{II})$

225 concentration and time were continuously monitored. After finishing with the coldest

226 subsample, the temperature of the water bath was increased to the following coldest 227 temperature, and the next sample was left to acclimate.

\subsubsection{Quantification of the temperature and $\mathrm{pH}$ effect on the iron (II) oxidation rate}

230 In order to improve the temperature range of the existing Fe(II) oxidation kinetic equation, 1

231 L samples of deep ocean water were collected during the JC156 cruise, at stations 13 (2339

$232 \mathrm{~m}), 16(2051 \mathrm{~m}), 24(2829 \mathrm{~m}), 30$ (2700 m), 31 (2796 m), and 35 (1999, 3350 and $3601 \mathrm{~m})$.

233 The samples remained frozen at $-20{ }^{\circ} \mathrm{C}$ during one year until analysis. Two days prior to the 
analysis, samples were thawed in a $4{ }^{\circ} \mathrm{C}$ fridge. This allowed a slow melting of the samples in the dark, thus limiting any photoproduction of Fe(II) and also removal of any superoxide and hydroxyl radicals in the sample (Voelker and Sedlak, 1995).

237 The samples were then transfered into $60 \mathrm{~mL}$ LDPE bottles (one for each condition).

238 Temperature effect experiments were performed at constant $\mathrm{pH}$, and those for $\mathrm{pH}$ effect at

239 constant temperature. The temperature effect experiments were carried out at in situ

240 temperature, 10,20 and $25{ }^{\circ} \mathrm{C}$ at a fixed $\mathrm{pH}$ of 8 . The $\mathrm{pH}$ effect experiments were carried out 241 at in situ $\mathrm{pH}$, and $\mathrm{pH} 7,7.5$ and 8 at a fixed temperature of $25{ }^{\circ} \mathrm{C}$.

\subsubsection{Oxidation rate constants through the water column at the six hydrothermal vent sites}

243 To assess the expected Fe(II) oxidation rate constants at in situ conditions, the experiments

244 were carried out at in situ potential temperature and $\mathrm{pH}\left(\mathrm{T}_{\mathrm{is}} \mathrm{pH}_{\mathrm{is}}\right)$. The temperature was then 245 increased to $25^{\circ} \mathrm{C}\left(\mathrm{T}_{25} \mathrm{pH}_{\text {is }}\right)$ to obtain the temperature effect on the oxidation rate constants.

246 A third set of experiments were performed at $25^{\circ} \mathrm{C}$ and $\mathrm{pH} 8\left(\mathrm{~T}_{25} \mathrm{pH}_{8}\right)$. The $\mathrm{T}$ and $\mathrm{pH}$ 247 normalization of all the samples allowed for the interpretation of the effect of other variables,

248 such as organic matter and particles, in the oxidation rate constants. This allows to investigate

249 where seawater composition is influencing the oxidation rate, a process that cannot be

250 isolated when comparing two samples with different temperatures and/or $\mathrm{pH}$.

\subsubsection{Experimental setup to assess the effect of colloidal and organic matter}

252 The unused unfiltered (UF) sample volumes remaining from the quantification of the

253 temperature and $\mathrm{pH}$ effect experiments were used to assess the impact of particles, colloids and organic matter. Unfiltered samples underwent sequential filtration. Three aliquots were filtered through $0.2 \mu \mathrm{m}\left(\mathrm{F} 0.2\right.$; Whatman ${ }^{\circledR}$ Anodisc), and one of them was then filtered through $0.02 \mu \mathrm{m}\left(\mathrm{F} 0.02\right.$; Whatman ${ }^{\circledR}$ Anotop $\left.{ }^{\circledR}\right)$, while the last aliquot was filtered through 

days to limit the effect of any photochemically generated reactive oxygen species (ROS) produced during the UV-irradiation (Yuan and Shiller, 2001; Roy et al., 2008). All samples were analyzed following the same procedure as for the assessment of the $\mathrm{pH}$ effect (see section 2.4.2 above). In order to assess whether the generated ROS species could affect the

$262 \mathrm{Fe}(\mathrm{II})$ oxidation rate constants determined after $0.02 \mu \mathrm{m}$ filtration and UV-irradiation, the effect of the amount of hydrogen peroxide $\left(\mathrm{H}_{2} \mathrm{O}_{2}\right)$ generated during this process was considered (Yuan and Shiller, 2001; O'Sullivan et al., 2005). Other short-lived ROS species such as hydroxyl radicals were not accounted for, since their nanosecond half-life times do not allow for their determination using our analytical method.

\section{Results}

\subsection{Temperature and $\mathrm{pH}$ effects on the oxidation rate constants}

269 Experiments for the temperature effect study were carried out at a $\mathrm{pH}$ of 8 . When plotting $\log$ $k^{\prime}$ vs. $1 / \mathrm{T}\left(\mathrm{K}^{-1}\right)$ (Fig. 2, Eq. 3), results showed an average slope $\left(-\Delta \mathrm{E}_{\mathrm{a}} / \mathrm{R} / \ln (10)\right)$ of $-4992 \pm$ 232. Notably, the data obtained from samples collected west of TAG at $2700 \mathrm{~m}$ depth (Station 30) showed a slope of $-3732 \pm 216$, which is more than three standard deviations away from the average value. This lower slope corresponds to a much lower activation energy for this sample, with a value of $71 \pm 4 \mathrm{KJ} \mathrm{mol}^{-1}$. This effect was probably caused by the interaction of organic compounds or particles with the Fe(II) species which affected the limiting Fe(II) oxidation step, and therefore a result of a different oxidation reaction mechanism. If this sample is removed, the average slope increases to $-5434 \pm 183$, and the activation energy of all the samples considered was $104 \pm 3 \mathrm{KJ} \mathrm{mol}^{-1}$. These values are within the experimental error of previous determinations from Gulf Stream water $(-5362 \pm 162$, and an activation energy of $103 \pm 3 \mathrm{KJ} \mathrm{mol}^{-1}$; Santana-Casiano et al., 2005). 
281 When experiments were carried out at a constant $\mathrm{T}$ of $25^{\circ} \mathrm{C}$ and at 5 different $\mathrm{pH}$ values in

282 the range from 7 to $8, \log k^{\prime}$ and $\mathrm{pH}$ were linearly related, with slopes of $1.00 \pm 0.06$ (Fig. 3)

283 and with no data points outside of 3standard deviations. As with the temperature relationship,

284 the sample from the station West of TAG at $2700 \mathrm{~m}$ presented a slope $(1.19 \pm 0.08)$ out of the

285 1:1 dependence. A second sample, (TAG at $1999 \mathrm{~m}$ depth, over $1600 \mathrm{~m}$ above the vent site)

286 showed a lower slope $(0.81 \pm 0.12)$.

287 The unique use of lower temperature samples in this study, allowed a better estimation of

$288 \mathrm{Fe}(\mathrm{II})$ oxidation kinetic rate constants at temperatures lower than $10^{\circ} \mathrm{C}$, increasing the range

289 of applicability of the Fe(II) oxidation kinetic equation of Santana-Casiano et al. (2005).

290 Using the equation and dataset from Santana-Casiano et al. (2005), which had a wider range

291 in $\mathrm{pH}$ and salinity, together with the additional $\mathrm{pH}$ data and a wider range of temperature

292 from the present study, a revised equation was obtained. The $\mathrm{pH}$ and salinity dependence did 293 not change, while the T relationship was modified (Eq. 4). Thus, an updated equation for the

294 theoretical Fe(II) oxidation appropriate for deep waters is presented:

$\log k^{\prime}\left(s^{-1}\right)=35.627-6.7109 * p H+0.5342 * p H^{2}-5434.02 / T-0.04406 * S^{1 / 2}-$

$296 \quad 0.002847 * S$

297 The $\mathrm{T}$ factor has been modified from $-5362.6 / \mathrm{T}$ to $-5434.02 / \mathrm{T}$ obtained from the average

298 slope of Figure 2. To assess the performance of the updated Fe(II) oxidation kinetic equation

299 (Eq. 4), it was compared to three existing equations. The chosen equations were the first

300 derived equation (Millero et al., 1987), the equation by Santana-Casiano et al. (2005), and a

301 recent equation using Labrador Seawater (Santana-González et al., 2019). The four equations

302 were compared to the measured oxidation rate constants at in situ $\mathrm{pH}$ and $\mathrm{T}$ conditions. The

303 residual sum of squares (RSS) and root mean square error (RMSE) between predicted and

304 observed values were calculated. Smallest values of RSS and RMSE indicate the best 
equation fit to observations. Additionally, the difference in logarithms of the likelihood

$306(\Delta \log (\mathrm{L}))$, based on a Gaussian error distribution with a constant variance of log-transformed

307 data, was used to compare the equation performance (Armstrong et al., 2001 and references

308 therein). The $\log (\mathrm{L})$ was calculated as in Moriceau et al. (2009), where a difference in $\log (\mathrm{L})$

309 of at least two points is considered as a criterion of a better fit to the observations. The three

310 most recent equations present better RSS, RMSE and $\log (\mathrm{L})$, with the new equation presented

311 here providing consistently better statistical results (Table 1).

\begin{tabular}{|c|c|c|c|c|}
\hline & $\begin{array}{l}\text { Millero et al. } \\
\text { (1987) }\end{array}$ & $\begin{array}{l}\text { Santana-Casiano } \\
\text { et al. (2005) }\end{array}$ & $\begin{array}{l}\text { Santana- } \\
\text { González et al. } \\
\text { (2019) }\end{array}$ & $\begin{array}{l}\text { González- } \\
\text { Santana et al. } \\
\text { (Eq. } 4 \text { of this } \\
\text { manuscript) }\end{array}$ \\
\hline RSS & 0.019 & 0.003 & 0.006 & 0.002 \\
\hline RMSE & 0.019 & 0.008 & 0.011 & 0.007 \\
\hline $\log (\mathrm{L})$ & 24.2 & 33.6 & 32.5 & 36.7 \\
\hline
\end{tabular}

312 Table 1. Statistical comparison of the available Fe(II) oxidation kinetic equations with the

313 measured oxidation rate constants for deep ocean waters without including the hydrothermal

314 neutrally buoyant plumes. Low residual sum of squares (RSS) and root mean square error

315 (RMSE) indicate the best equation fit to observations. Greater than two points of difference

316 in the difference in logarithms of the likelihood $(\Delta \log (\mathrm{L}))$ presents a better fit.

\subsection{Iron(II) oxidation rate constants throughout hydrothermal plumes along the MAR}

318 Figures 4 and 5 present the half-life times of Fe(II) samples collected above each

319 hydrothermal site with Figure 5 summarizing the results using boxplots. The measured $t_{1 / 2}$ 
values presented a wider range than those determined using the physico-chemical parameters in the improved theoretical equation. The Lost City vent site, was the only station where all the measured $\mathrm{t}_{1 / 2}$ at $\mathrm{T}_{\text {is }} \mathrm{pH}_{\mathrm{is}}$ conditions presented measured oxidation rate constants higher (shorter $\mathrm{t}_{1 / 2}$ ) than the theoretically calculated rate constants. At $\mathrm{T}_{25} \mathrm{pH}_{8}$ conditions, all the measured oxidation rate constants were higher than the theoretical ones for all stations except at TAG.

The theoretical $t_{1 / 2}$ values presented in Figure 5a, show the expected high variability in the $\mathrm{Fe}(\mathrm{II})$ half-life times associated with $\mathrm{T}, \mathrm{pH}$ and $\mathrm{S}$. These discrepancies were further highlighted in the measured samples, where only Menez Gwen and Lucky Strike theoretical values are within the measured results (a paired t-test did not show a statistical difference between the theoretical and the measured $\mathrm{t}_{1 / 2}$, with $\mathrm{P}>0.35$ for both).

At Menez Gwen (Fig. 4a), measured in situ $\mathrm{t}_{1 / 2}$ varied between 8.3 and 32.0 min ( $k$ ' between 0.084 and $0.022 \mathrm{~min}^{-1}$ ), with short measured $\mathrm{t}_{1 / 2}$ observed in the samples collected at 743 , 821 , and $827 \mathrm{~m}$. When the temperature was increased and fixed to $25^{\circ} \mathrm{C}$, while the $\mathrm{pH}$ was kept at in situ conditions (Supplementary Table S1), a significant T effect was observed in $k$, with the measured $t_{1 / 2}$ decreasing to less than 4 min. When the $\mathrm{pH}$ was fixed to a constant value of 8 along the water column, the measured $t_{1 / 2}$ was slightly affected indicating a small effect, as the change in $\mathrm{pH}$ was always lower than 0.22 . Overall, at $\mathrm{T}_{25}$, samples presented measured $\mathrm{t}_{1 / 2}$ in the same order of magnitude as the theoretical $\mathrm{T}_{25} \mathrm{pH}_{8}$. Samples collected within the lower part of the plume, at less than $30 \mathrm{~m}$ above the seafloor (hereafter asf)

340 presented higher oxidation rate constants than theoretical ones ( $\mathrm{t}_{1 / 2}$ decreased).

341 Lucky Strike (Fig. 5a) presented lower oxidation rate constants than Menez Gwen related to 342 lower temperatures in deeper waters (from about $8.5^{\circ} \mathrm{C}$ to $4.5^{\circ} \mathrm{C}$ ). From $1600 \mathrm{~m}$ to $1680 \mathrm{~m}$, 343 measured $\mathrm{t}_{1 / 2}$ averaged $46.5 \pm 2.5 \min \left(k^{\prime}\right.$ of $\left.0.015 \pm 0.001 \mathrm{~min}^{-1}, \mathrm{n}=4\right)($ Fig. $4 \mathrm{~b})$. This $\mathrm{t}_{1 / 2}$ 
average is higher than the theoretical value of $39.7 \mathrm{~min}$, while at $1703 \mathrm{~m}$, the Fe(II) half-life decreased to $26.3 \mathrm{~min}\left(k^{\prime}\right.$ to $\left.0.026 \mathrm{~min}^{-1}\right)$. Overall, at $\mathrm{T}_{25}$, samples presented measured $\mathrm{t}_{1 / 2}$ in the same order of magnitude as the theoretical $\mathrm{T}_{25} \mathrm{pH}_{8}$. In situ $\mathrm{pH}$ averaged 7.89 , where the increase in acidity produced a lower oxidation rate constant than the measured $\mathrm{t}_{1 / 2}$ at $\mathrm{T}_{25} \mathrm{pH}_{8}$.

348 At Rainbow, station 16, the $\mathrm{t}_{1 / 2}$ measured at in situ conditions presented a wide range of variation, from 17.3 to $65.3 \mathrm{~min}\left(k^{\prime}\right.$ varied from $0.040 \mathrm{~min}^{-1}$ to $\left.0.011 \mathrm{~min}^{-1}\right)$. The theoretically expected values were within that range, with an average value of $39 \pm 3 \min (n=8$, Fig. $4 c)$. The shortest $\mathrm{t}_{1 / 2}$ were observed between $1986 \mathrm{~m}$ and $2108 \mathrm{~m}$ (175 to $295 \mathrm{~m}$ asf) averaging $22.2 \pm 3.6 \min \left(k^{\prime}=0.032 \pm 0.006 \mathrm{~min}^{-1}\right)$ while the shorter $\mathrm{t}_{1 / 2}$ were found below the plume and above $300 \mathrm{~m}$ asf (Fig. 4c). The light scattering data shows that the Rainbow plume reached heights over $400 \mathrm{~m}$ asf (although samples were only collected within the first $330 \mathrm{~m}$ ).

355 Temperature was an important factor controlling the oxidation rate constant. At $\mathrm{T}_{25}$ conditions $\mathrm{t}_{1 / 2}$ were similar to the theoretical value. When the $\mathrm{pH}$ was fixed to 8 , small changes were observed, and most of the values were close to the theoretical value except for those around $1986 \mathrm{~m}$ and $2108 \mathrm{~m}$ which had shorter $\mathrm{t}_{1 / 2}$.

Lost City (Fig. 4d), the only alkaline hydrothermal vent, was drastically different from the

360 other hydrothermal sites (Fig. $4 \mathrm{~d}$ ), with temperatures around $10^{\circ} \mathrm{C}$ and $\mathrm{pH}_{\text {is }}$ of 8.07

361 (Supplementary Table $\mathrm{S} 1$ ). The theoretical $\mathrm{t}_{1 / 2}$ associated with these temperatures and $\mathrm{pH}$ ranged between 16 and 20 min. However, most of the measured $t_{1 / 2}$ were shorter than 3 min, reaching $0.5 \mathrm{~min}\left(k^{\prime}\right.$ of $\left.1.299 \mathrm{~min}^{-1}\right)$ at $725 \mathrm{~m}$ with the longest $\mathrm{t}_{1 / 2}$ of $7.8 \mathrm{~min}\left(k^{\prime}\right.$ of $0.088 \mathrm{~min}^{-}$ $\left.{ }^{1}\right)$ at $750 \mathrm{~m}$. At $750 \mathrm{~m}$ depth with $\mathrm{T}_{25} \mathrm{pH}_{\text {is }}$ conditions, the $\mathrm{t}_{1 / 2}$ decreased to $1.9 \mathrm{~min}\left(k^{\prime}\right.$ of 0.357 $\left.\min ^{-1}\right)$ and further decreased to $1.5 \mathrm{~min}\left(k^{\prime}\right.$ of $\left.0.468 \mathrm{~min}^{-1}\right)$ at $\mathrm{T}_{25} \mathrm{pH}_{8}$ conditions. All the 366 measured $t_{1 / 2}$ were significantly shorter than the theoretical $t_{1 / 2}$ of $3.2 \min \left(k^{\prime}\right.$ of 0.218 min $\left.^{-1}\right)$ at normalized conditions. 
368 Broken Spur presented a wide range in measured $t_{1 / 2}$, with values under in situ conditions ranging from 1.0 to $65.1 \mathrm{~min}\left(k^{\prime}\right.$ ranging from $0.714 \mathrm{~min}^{-1}$ at $2929 \mathrm{~m}$ to $0.011 \mathrm{~min}^{-1}$ at 2858 m; Fig. 4e). Two different behaviors can be observed. The two shallowest samples (2820 and $2830 \mathrm{~m}$ ) were collected in local light scattering minima, with $\mathrm{t}_{1 / 2}$ averaging $63.2 \pm 2.7 \mathrm{~min}\left(k^{\prime}\right.$ of $0.011 \pm 0.001 \mathrm{~min}^{-1}$ ) and values slightly higher than the theoretical ones. Deeper than 2830 $\mathrm{m}$, the samples were collected in local light scattering maxima, where half-life times were shorter with an average $t_{1 / 2}$ of $1.9 \pm 1.2 \mathrm{~min}$ (averaged $k^{\prime}$ of $0.464 \pm 0.220 \mathrm{~min}^{-1}$ ). values) than what was theoretically expected.

Half-life times measured at in situ conditions from the TAG vent site samples presented the widest range in $\mathrm{t}_{1 / 2}$ (Figs. 4 and 5a), varying from 35.1 to $131.2 \mathrm{~min}$ ( $\mathrm{k}$ ' between $0.019 \mathrm{~min}^{-1}$ and $\left.0.005 \mathrm{~min}^{-1}\right)$. These samples were characterized by little variability of $\mathrm{T}_{\text {is }}\left(2.67 \pm 0.01{ }^{\circ} \mathrm{C}\right)$ and $\mathrm{pH}_{\text {is }}(8.17 \pm 0.01)$, producing a stable theoretical $\mathrm{t}_{1 / 2}$ of $43 \pm 2 \mathrm{~min}$. Furthermore, the measured $t_{1 / 2}$ were the longest obtained in these experiments. When the experiments were repeated at both fixed $\mathrm{T}_{25}$ and $\mathrm{pH}_{8}$ the measured values encompassed the theoretical value of 3.3 min, with values slightly higher at around $3325 \mathrm{~m}$ (4.3-4.4 min). Therefore, even when temperature and $\mathrm{pH}$ affected the observed oxidation rate constants, the high range of values at in situ conditions could not be explained by only these two physico-chemical variables.

\subsection{Investigating the spatial variability of Fe(II) oxidation rate constants around Rainbow} and TAG sites

To investigate the spatial variability in $\mathrm{t}_{1 / 2}$ for $\mathrm{Fe}(\mathrm{II})$, samples were collected from four stations around the Rainbow site at $0.3^{\circ}(30 \mathrm{~km}) \mathrm{S}(\mathrm{St} 15), \mathrm{E}(\mathrm{St} 12)$ and W (St 13) and $1^{\circ}$

390 (120 km) E (St 10) (Fig. 1) and from five stations around TAG at 0.3 ${ }^{\circ} \mathrm{N}$ (St 26), S (St 27), W

391 (St 30), and E (St 31) and $1^{\circ} \mathrm{W}$ (St 29) (Fig. 1). At both vent sites, turbidity and light 
scattering anomalies matched and described the shape of the plume (gray shading in Fig. 4).

393 The Rainbow plume anomaly was observed between 1930-1995 m, 2060-2090 m, and most

394 strongly between 2100 and $2210 \mathrm{~m}$. At the TAG site, the signal was three times lower than

395 that observed at Rainbow, indicating the presence of a lower amount of particles, which could

396 also be due to a displacement of the sampling with respect to the vent site. The largest

397 anomalies were measured between $3160-3390 \mathrm{~m}$, with several minor anomalies above (e.g.

398 2980-3030 m) and below (e.g. 3430-3520 m and 3600-3625 m; Fig. 4).

399 Turbidity and light scattering were useful for tracking the plume displacement even at $30 \mathrm{~km}$

400 from the vent site. The Rainbow plume was observed to the south and west (Stn. 13 and 15)

401 at depths between 2000 and 2040 m, and 2270 and 2300 m. For TAG, only stations 27 (south

402 of TAG, but inside the MAR valley) and 31 (east) showed deeper and thinner turbidity

403 anomalies between 3400 and $3690 \mathrm{~m}$ and a smaller signal between 2920 and $3060 \mathrm{~m}$.

404 For the Rainbow field, samples collected at the vent site in the 1980-2150 m range had

405 shorter $\mathrm{t}_{1 / 2}$ at in situ conditions (high $k^{\prime}$ values) than the theoretical $\mathrm{t}_{1 / 2}$ (Fig. 6a). All the other

406

samples (except for $\operatorname{Stn} 10$ at $2430 \mathrm{~m}$ ) had higher $\mathrm{t}_{1 / 2}$ values than those calculated

407 theoretically, and greater $\mathrm{t}_{1 / 2}$ than observed at Rainbow at depths shallower than $1980 \mathrm{~m}$,

408 indicating very low oxidation rate constants. This allowed $\mathrm{Fe}(\mathrm{II})$ to stay in solution three

409 times longer than under inorganic seawater conditions. However, when $\mathrm{T}$ and $\mathrm{pH}$ were fixed

410 (Fig. 6b), the oxidation rate constants between stations were much closer to the theoretical

411 value, indicating the $\mathrm{T}$ and $\mathrm{pH}$ control over the $\mathrm{Fe}(\mathrm{II})$ oxidation rate constant. Nevertheless,

412 plume samples at the $2100-2210 \mathrm{~m}$ range and around $2400 \mathrm{~m}$ indicated $\mathrm{t}_{1 / 2}$ values that were

413 still at least double the theoretical value.

414 At the TAG hydrothermal field, stations situated towards the $\mathrm{N}$ and $\mathrm{W}$ of TAG presented

415 shorter $\mathrm{t}_{1 / 2}$ (high $k^{\prime}$ values) than those at the vent site and towards the $\mathrm{S}$ and $\mathrm{E}$ (Fig. 7a). 
416 Station 30 , situated $30 \mathrm{~km} \mathrm{~W}$ of TAG, exhibited both patterns, with long $\mathrm{t}_{1 / 2}$ (low $k^{\prime}$ values) at

417 depths shallower than $2600 \mathrm{~m}$ and short $\mathrm{t}_{1 / 2}$ (high $k^{\prime}$ values) at depths below $2700 \mathrm{~m}$. When

418 all the TAG hydrothermal field station samples were normalized (i.e. $\mathrm{T}_{25} \mathrm{pH}$; Fig. $7 \mathrm{~b}$ ), most

419 of the variability was removed, and $\mathrm{t}_{1 / 2}$ averaged $3 \pm 1.5 \mathrm{~min}$. The same pattern as for in situ

420 conditions was maintained, with stations situated towards the $\mathrm{N}$ and $\mathrm{W}$ having shorter $\mathrm{t}_{1 / 2}$

421 than the theoretical values. These three stations were characterized by their lower turbidity in 422 the deep waters.

\subsection{The effect of particles, colloids, and organic matter on oxidation rate constants}

424 Experiments with samples from Rainbow (Stn 16, 2051 m), West of Rainbow (Stn 13, 2339

425

m), Broken Spur (Stn 24, $2829 \mathrm{~m}$ ) and TAG (Stn 35, $3350 \mathrm{~m}$ ) were performed to improve our

understanding of the impact of particulate and organic matter on the oxidation kinetics of

hydrothermal vent fluids. The Rainbow sample at $2051 \mathrm{~m}$, located outside the plume, did not show any difference in the $\log \left(k^{\prime}\right)$ due to the presence of particulates, with values at each $\mathrm{pH}$ unit varying by \pm 0.03 and an average slope of $\log \left(k^{\prime}\right)$ against $\mathrm{pH}$ of $0.96 \pm 0.07$ for UF, F0.2 and F0.02 treatments (Fig. 8). For the other three samples (Figs. 8b-d), oxidation rate constants for UF and F0.2 did not present significant differences, with values that were reproducible within \pm 0.02 for the studied $\mathrm{pH}$ range. However, F0.02 samples had higher oxidation rate constants, while also maintaining the $\mathrm{pH}$ dependence $(0.95 \pm 0.07)$. Therefore, the presence of colloidal size particles delayed the oxidation process while not affecting the $\mathrm{pH}$ dependence, as shown in Fig. 8, where the intercept changes but the slope is unchanged. All of the UV irradiated samples in Figs. 8a-d indicate that the absence of dissolved organic matter increased the oxidation rate constants. For TAG (3350 m) and Rainbow (2051 m), the

$438 \mathrm{k}$ ' values were so high that it was impossible to determine them at $\mathrm{pH}=8$ under our experimental conditions. 


\subsection{Derived oxidation rate constants as a function of $\mathrm{pH}$ and temperature}

442 In the 1990s, Fe(II) oxidation kinetics variability was reported at the TAG hydrothermal field 443 (2-3 min) (Rudnicki and Elderfield, 1993) and near the Juan de Fuca Ridge hydrothermal systems (32 h) (Chin et al., 1994; Massoth et al., 1994) using the Millero et al. (1987) equation. Nevertheless, the variability between those two sites was difficult to explain and reflected fluctuations caused by differences in $\mathrm{O}_{2}$, $\mathrm{T}$, and $\mathrm{pH}$ among the different sites.

447 When combining the six hydrothermal vent sites on the MAR (Fig. 9), the relationship

448 between the measured oxidation rate constants under in situ conditions against the

449 theoretically derived oxidation rate constants as a function of $\mathrm{pH}$ and temperature (in aerated water) can be obtained. Overall, equation 4 can explain 76 out of 104 data points. When color-coding the data points by stations, we observed that all the outliers corresponded to samples that were collected inside hydrothermal plumes (defined by turbidity, light scatter, and redox potential). Consequently, the results obtained from the theoretical equation (Eq. 4) and figure 9, agree well with previous results that $\mathrm{O}_{2}, \mathrm{~S}, \mathrm{~T}$, and $\mathrm{pH}$ can be used to characterize the $\mathrm{Fe}(\mathrm{II})$ oxidation rate constant in open ocean waters but not from within hydrothermal plumes.

457 Our study clearly indicates (Figs. 8 and 9) that the presence of both colloidal particles and 458 dissolved organic matter increases the half-life of $\mathrm{Fe}(\mathrm{II})$ (decreased $k^{\prime}$ ). This agrees with 459 previous work showing a decrease in the Fe(II) oxidation rate constants in seawater in the 460 presence of some natural organic compounds (Santana-González et al., 2019). However, organic matter can have a positive or negative effect on the oxidation rate constants of $\mathrm{Fe}(\mathrm{II})$ depending on the type of organic matter and its degree of remineralization (Rose and Waite, 
2003). The variability in the effect of total organic carbon on Fe(II) oxidation proves that total organic carbon cannot be used as a variable in an equation describing $k^{\prime}$ (SantanaCasiano et al., 2000; Santana-González et al., 2018; Santana-González et al., 2019). In this sense, a more detailed characterization of organic matter would be necessary, especially in a

467 hydrothermal environment.

\subsection{Influence of organic species on Fe(II) oxidation rate constants}

469

470

471

472

473

474

475

476

477

478

479

480

481

482

483

The Fe(II) oxidation rate constant (Eq. 5) can be expressed as a function of each $\mathrm{Fe}(\mathrm{II})$ species $\left(\mathrm{Fe}^{2+}, \mathrm{FeOH}^{+}, \mathrm{Fe}(\mathrm{OH})_{2}, \mathrm{FeHCO}_{3}{ }^{+}, \mathrm{Fe}\left(\mathrm{CO}_{3}\right), \mathrm{Fe}\left(\mathrm{CO}_{3}\right)_{2}{ }^{2-}, \mathrm{Fe}\left(\mathrm{CO}_{3}\right) \mathrm{OH}^{-}, \mathrm{FeCl}^{+}, \mathrm{FeSO}_{4}\right.$, $\mathrm{FeH}_{3} \mathrm{SiO}_{4}$ and any organically complexed $\mathrm{Fe}$ species). Species such as $\mathrm{Fe}\left(\mathrm{CO}_{3}\right)_{2}{ }^{2-}$ and $\mathrm{Fe}(\mathrm{OH})_{2}$ could become important at pH higher than 8 (Ussher et al., 2004; González-Davila et al., 2005; Santana-Casiano et al., 2005) in solution. Considering the side reaction coefficient for each inorganic $\left(\alpha_{i}\right)$ and organic $\left(\alpha_{j}\right) \mathrm{Fe}(\mathrm{II})$ species in seawater and the associated second-order oxidation rate constant for the kinetically reactive $\mathrm{Fe}(\mathrm{II})$ species $\left(k_{\mathrm{i}}\right.$ and $k_{\mathrm{j}}$ ) (Eq. 6) (Millero and Sotolongo, 1989; King, 1998; Santana-Casiano et al., 2005), the apparent oxidation rate constant can be expressed as:

$k_{\mathrm{app}}=k_{\mathrm{Fe}^{2+}} \alpha_{\mathrm{Fe}^{2+}}+k_{\mathrm{FeOH}}{ }^{+} \alpha_{\mathrm{FeOH}^{+}}+k_{\mathrm{Fe}(\mathrm{OH})_{2}} \alpha_{\mathrm{Fe}(\mathrm{OH})_{2}}+k_{\mathrm{FeHCO}_{3}^{+}} \alpha_{\mathrm{FeHCO}_{3}^{+}}+$

$k_{\mathrm{Fe}\left(\mathrm{CO}_{3}\right)} \alpha_{\mathrm{Fe}\left(\mathrm{CO}_{3}\right)}+k_{\mathrm{Fe}\left(\mathrm{CO}_{3}\right)_{2}^{2-}} \alpha_{\mathrm{Fe}\left(\mathrm{CO}_{3}\right)_{2}^{2-}}+k_{\mathrm{Fe}\left(\mathrm{CO}_{3}\right) \mathrm{OH}^{-}} \alpha_{\mathrm{Fe}\left(\mathrm{CO}_{3}\right) \mathrm{OH}^{-}}+k_{\mathrm{FeCl}^{+}} \alpha_{\mathrm{FeCl}^{+}}+$

$k_{\mathrm{FeSO}_{4}} \alpha_{\mathrm{FeSO}_{4}}+k_{\mathrm{FeH}_{3} \mathrm{Si}}{ }_{4} \alpha_{\mathrm{FeH}_{3} \mathrm{SiO}_{4}}+\sum_{j} k_{\mathrm{FeL}_{j}} \alpha_{\mathrm{FeL}_{j}}$

$k_{\mathrm{app}}=\sum_{i} \alpha_{i} k_{i}+\sum_{j} \alpha_{j} k_{j}$

$\alpha_{F e^{2+}}=1 /\left(1+\sum K_{L_{i}}\left[L_{i}\right]+\sum K_{L_{j}}\left[L_{j}\right]\right)$

Where $\alpha_{F e} e^{2+}$ is the fraction of free Fe(II) including inorganic and organic speciation, $\left[\mathrm{L}_{\mathrm{i}}\right]$ is the concentration of each inorganic ligand with a conditional stability constant $K_{i}$ and $\left[L_{j}\right]$ is 
the concentration of each organic ligand with a conditional stability constant $K_{L j}$. The inorganic site reaction coefficient at $\mathrm{pH} 8$ and $25^{\circ} \mathrm{C}$ was previously determined as 0.38

487 (Santana-Casiano et al., 2006). For any inorganic or organic FeL complexes:

$\alpha_{F e L}=K_{F e L}[L] \alpha_{F e^{2+}}$

489 According to our results, the presence of DOM in solution generated Fe(II)-organic complexes that were overall less reactive to oxidation and therefore, when removed by UV irradiation the resulting oxidation rate constants were higher (Fig. 8).

492 The amount of dissolved organic carbon (DOC) in the samples ranged between 50 and 79 $\mu$ mol kg-1 (data not shown) and according to O'Sullivan et al. (2005) the maximum amount

494 of $\mathrm{H}_{2} \mathrm{O}_{2}$ produced during irradiation could be 125 to $147 \mathrm{nmol} \mathrm{kg}^{-1}$, respectively. Following 495 González-Davila et al. (2005) and assuming the extreme case of no $\mathrm{H}_{2} \mathrm{O}_{2}$ decay after 6 days, 496 the UV generated $\mathrm{H}_{2} \mathrm{O}_{2}$ could theoretically increase the $\mathrm{Fe}(\mathrm{II})$ oxidation rate constants in oxygen saturated conditions. The theoretical $\mathrm{t}_{1 / 2}$ associated with the $\mathrm{H}_{2} \mathrm{O}_{2}$ oxidation was between $48 \%$ and $53 \%$ of the $\mathrm{t}_{1 / 2}$ measured for $0.02 \mu \mathrm{m}$ filtered samples. Nevertheless, the measured $\mathrm{t}_{1 / 2}$ for UV-irradiated samples (Supplementary Table S1 and Fig. 8) were shorter

500 (higher $k^{\prime}$ ), indicating that any $\mathrm{H}_{2} \mathrm{O}_{2}$ remaining in solution after 6 days was not the main

501 factor that increased the oxidation rate constants and that the presence of dissolved organic matter was stabilizing Fe(II) in solution. Furthermore, laboratory experiments have shown

503 that the $\mathrm{t}_{1 / 2}$ of $\mathrm{H}_{2} \mathrm{O}_{2}$ in oceanic waters is shorter than 5.5 days (Yuan and Shiller, 2001),

504 therefore the impact of $\mathrm{H}_{2} \mathrm{O}_{2}$ in the experiments would be further reduced.

505 The role of organically complexed Fe(II) could be calculated from the following 506 assumptions. Firstly, the Fe(II)-L complex was assumed to not oxidize in the pH range of 7.5 to 8 . Secondly, the observed reduction in Fe(II) oxidation rate constants (Fig. 8 and 
508 Supplementary Table S1) at $25^{\circ} \mathrm{C}$ between the $0.02 \mu \mathrm{m}$ filtered and the filtered and UV

509 irradiated samples was due to organic complexation. The computed role of organic

510 complexation produced a $78 \pm 6 \%$ decrease in the concentration of reactive inorganic $\mathrm{Fe}(\mathrm{II})$

511 species. The effect of organic Fe(II) species was highest at Broken Spur and TAG sites $(81 \pm$

$5125 \%)$ and lowest at Rainbow (74.1 $\pm 4 \%)$. Roy et al. (2008) found a value that was slightly

513 lower for the western subarctic Pacific water, with a $61 \pm 8 \%$ decrease. As both the organic

514 ligand concentrations and the conditional constants are unknown, only the product $K_{L j} \cdot\left[L_{j}\right]$

515 (Eq. 7) can be inferred. Knowing the inorganic distribution coefficient of Fe(II), which is $\mathrm{pH}$

516 dependent but can be calculated from Santana-Casiano et al., (2005), and considering a

517 unique class of ligand (L), the product $K_{L j} \cdot\left[L_{j}\right]$ should be $9 \pm 2$ (higher values at Broken Spur

518 and TAG, while lower values at Rainbow) while $1+\sum K_{L_{i}}\left[L_{i}\right]$ in Eq. 7 is $2.6(2.6=1 / 0.38$,

519 Santana-Casiano et al., (2006)).

520 If the concentration of $\mathrm{Fe}(\mathrm{II})$ organic ligands in seawater is on the same order as $\mathrm{Fe}(\mathrm{III})$

521 ligands ( 1 to $10 \mathrm{nmol} \mathrm{L}^{-1}$ ), as assumed by Roy et al. (2008), the corresponding conditional 522 constant should range between $10^{9}$ to $10^{10}$, (respectively for 10 and $1 \mathrm{nmol} \mathrm{L}^{-1}$ of ligands).

523 The strength of these Fe(II) complexing ligands compared to those for Fe(III) is in the low 524 affinity range (Gledhill and Buck, 2012; Bundy et al., 2014). However, the formation of these 525 complexes would decrease the Fe(II) oxidation rate constant through both the effects on the 526 side reaction coefficients (Eqs. 7-8) and because the complexes can be non-reactive to 527 oxidation or may oxidize slower than other inorganic species. Moreover, it should be 528 considered that organic matter might even increase the Fe(II) $t_{1 / 2}$ due to the reduction of 529 organically complexed Fe(III), which would increase the Fe(II) in solution, and therefore the $530 \mathrm{t}_{1 / 2}$ (Santana-Casiano et al., 2010). 
531 The UV-irradiation treatment (Fig. 8) removes the organic matter effect on the Fecomplexation, which for the studied samples resulted in an increase in the oxidation rate constants. Consequently, in these analyzed natural samples, organic matter ultimately

534 lowered the oxidation rate constants (black data points below the straight line in Fig. 9).

535 The DOM is prone to natural and thermal degradation in hydrothermal systems (Hawkes et

536 al., 2016). Accordingly, the variety of organic-complexing ligands and their effect on

537 oxidation could change with plume transport and distance to the vent site as observed in

538 figures 6 and 7. In the proximities to the vent sites, samples presented greater than theoretical 539 oxidation rate constants (above the straight line in Fig. 9). This could be due to the presence 540 of organic matter with ligands complexing Fe that oxidizes faster than the inorganic Fe(II)

541 species. At these locations, the organic ligand effect would dominate over processes that

542 lower oxidation rate constants such as nanoparticle concentrations. Similar experiments 543 considering organic matter degradation just above the vent site should be carried out to 544 confirm this hypothesis. Nevertheless, the complexity of the organic matter pool and the 545 extent and nature of Fe-DOM interactions make the resulting effect on the oxidation rate 546 constants difficult to predict.

\section{4.3. Effects of physical speciation}

548 Lough et al. (2019) have shown that there is an Fe exchange between the different particle

549 size fractions within the hydrothermal plume. This exchange could affect Fe(II) oxidation as 550 found in this study for particles smaller than $0.2 \mu \mathrm{m}$ and colloidal sized particles (0.2-0.02 $551 \mu \mathrm{m}$ ) at different locations in TAG and in Rainbow (Fig. 8). The results shown in Figure 8 552 seem to indicate that the size-fractionation can significantly affect $\mathrm{Fe}(\mathrm{II})$ oxidation and thus, 553 is a factor that should be considered in future studies. In this sense, previous work has shown 554 that particulate $\mathrm{Fe}(\mathrm{II})$, such as pyrite nanoparticles are more resistant to oxidation, with $\mathrm{Fe}(\mathrm{II})$ 
half-life between 4 and 48 months at $2{ }^{\circ} \mathrm{C}$ (Yücel et al., 2011). The presence of colloidal

556 particles also enhances the decay of ROS allowing for longer $\mathrm{t}_{1 / 2}$ (Yuan and Shiller, 2001).

557 Therefore, nanoparticles could account for a substantial fraction of the decrease in the

558 oxidation rate constants (Fig. 8). Another consequence of filtration is the reduction in larger

559 size organic matter, which could also affect the stabilization of Fe(II) (Buck et al., 2015).

560 The variability observed in the oxidation rate constants inside the plume for the six studied

561 hydrothermal vents indicates that changes in the composition of both the DOM and colloidal

562 particles, both between sites and at different distances from the vent, can strongly affect the

563 oxidation rate constants, thus, their role requires further study.

\section{Conclusions}

565 This study highlights the complexity of Fe(II) chemistry in the ocean, with a focus on

566 hydrothermal vent settings. Fe(II) oxidation rate constants, and therefore persistence of Fe(II)

567 in the environment, is shown to not only depend on the physico-chemical conditions (T, S,

$568 \mathrm{pH}, \mathrm{O}_{2}$ content) but also the physical state (soluble, colloidal and particulate) of the inorganic

569 and organic species that are present. Our results indicate that organic ligands can stabilize

$570 \mathrm{Fe}(\mathrm{II})$ and that nanoparticles present in hydrothermal plumes could increase the resistance to

571 oxidation. Both processes contribute to the observed variability in the oxidation rate constants

572 in the proximities of vents. We were able to revise the theoretical equation for the estimation

573 of $k^{\prime}$, and to further increase the existing temperature range to include seawater temperatures

574 as low as $2{ }^{\circ} \mathrm{C}$. Future studies on iron oxidation kinetics in the marine environment should be

575 accompanied by a characterization of the organic matter present in the medium, a size-

576 fractionation of the samples, and a detailed description of the conventional physico-chemical

577 factors $(\mathrm{pH}, \mathrm{T}$, and $\mathrm{S})$. 
$578 \quad$ Figures

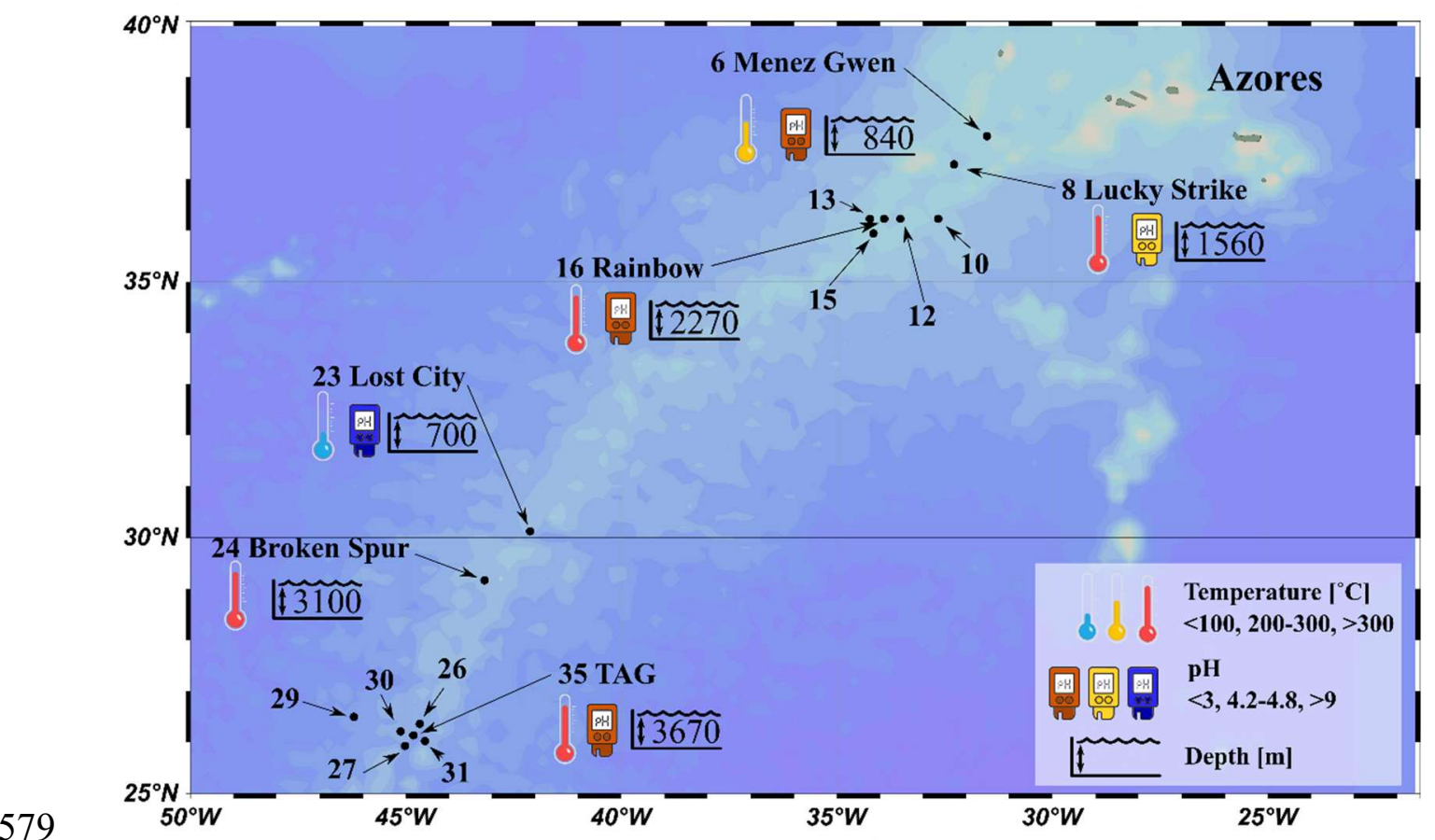

580 Figure 1. Map of the investigated hydrothermal vent sites along the MAR, showing the

581 station numbers and hydrothermal vent site names for the sampling sites. Symbols represent

582 endmember characteristics. The $\mathrm{pH}$ of the Broken Spur endmember was not available. 


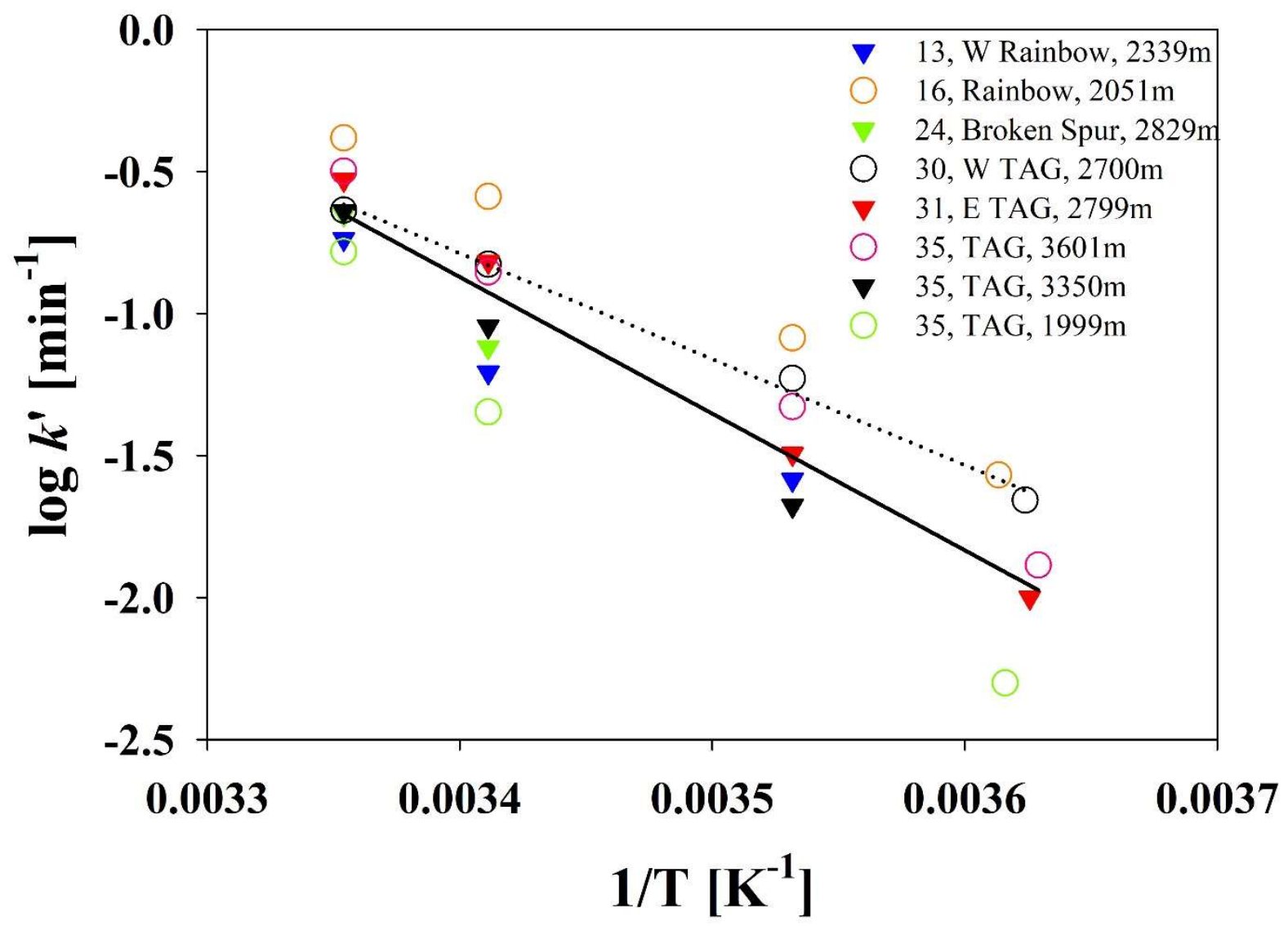

583

584 Figure 2. Arrhenius relationship between the oxidation rate constant $\left(\log k^{\prime}\left(\min ^{-1}\right)\right)$ and

585 temperature $\left(1 / \mathrm{T}\left(\mathrm{K}^{-1}\right)\right)$ in the range 2 to $25^{\circ} \mathrm{C}$ for eight selected samples. Note that the

586 sample from station 30 (W TAG, 2700m, open squares, dotted line) shows a different

587 behavior than samples from other stations. 


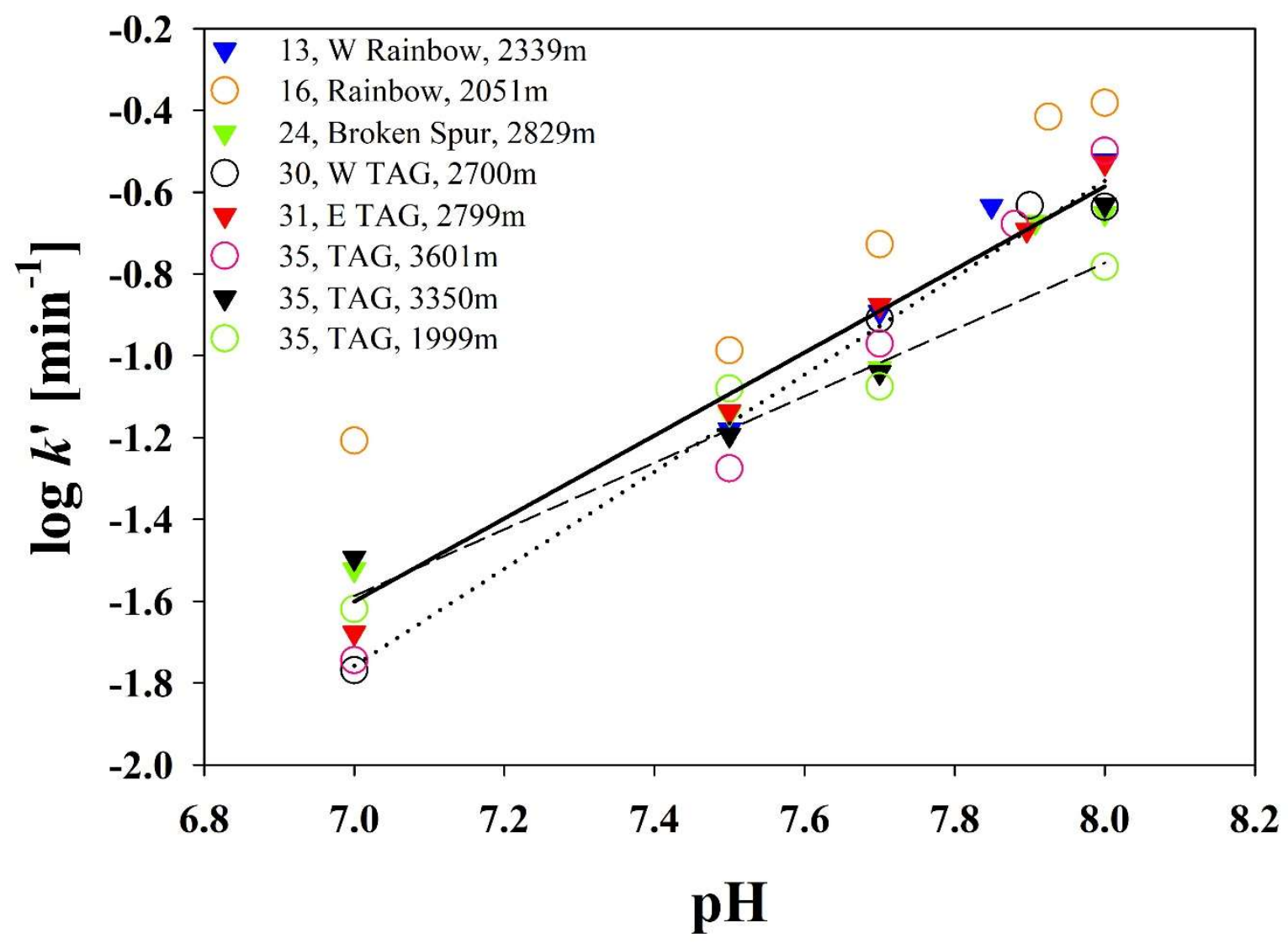

589 Figure 3. $\mathrm{pH}$ effect (from 7.0 to 8.0 ) on the $\mathrm{Fe}(\mathrm{II})$ oxidation rate constants $\left(\log k^{\prime}\left(\mathrm{min}^{-1}\right)\right.$ ) for

590 eight selected samples collected along the MAR. Note that the samples from $2700 \mathrm{~m}$ depth to

591 the west of TAG (Stn 30, open squares) and from $1999 \mathrm{~m}$ depth at the TAG site (Stn 35, open

592 diamonds) have different slopes than samples from other stations (data from these two

593 stations are plotted with dotted lines). 

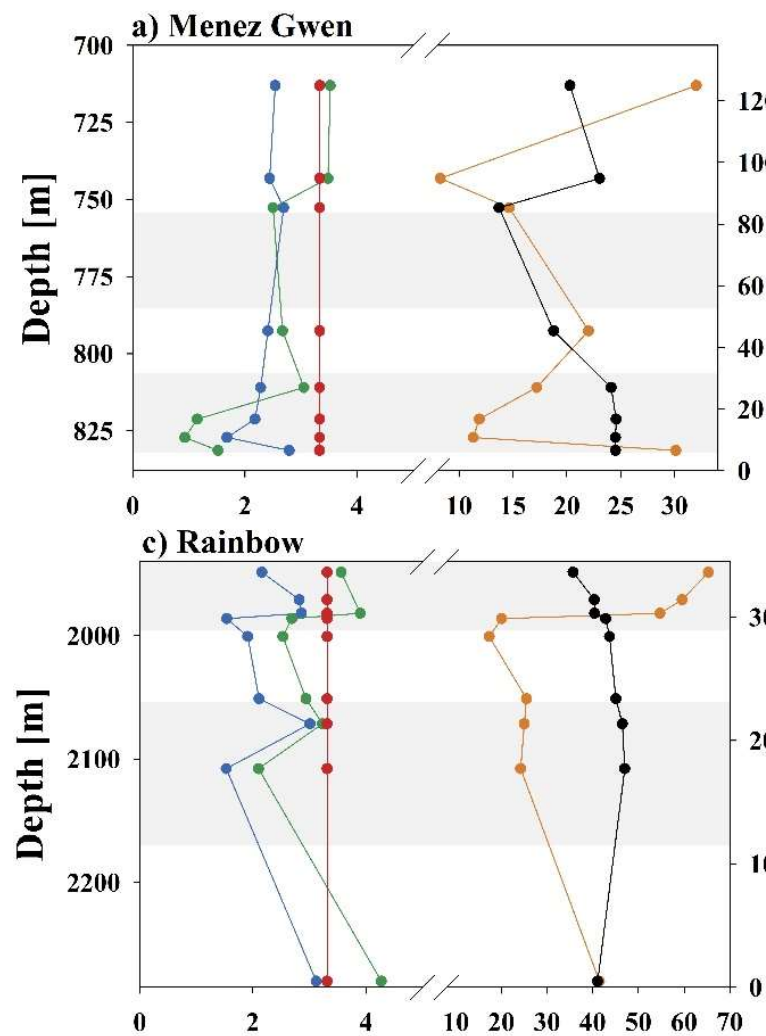

e) Broken Spur

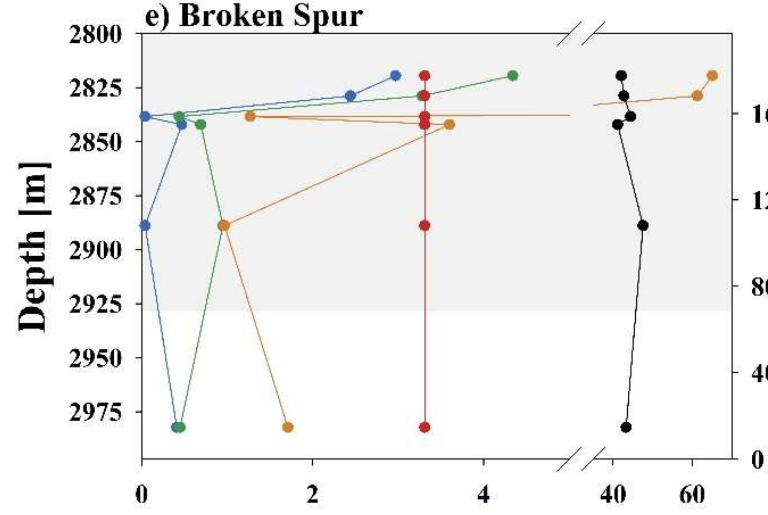

$\mathbf{t}_{1 / 2}[\min ]$ b) Lucky Strike

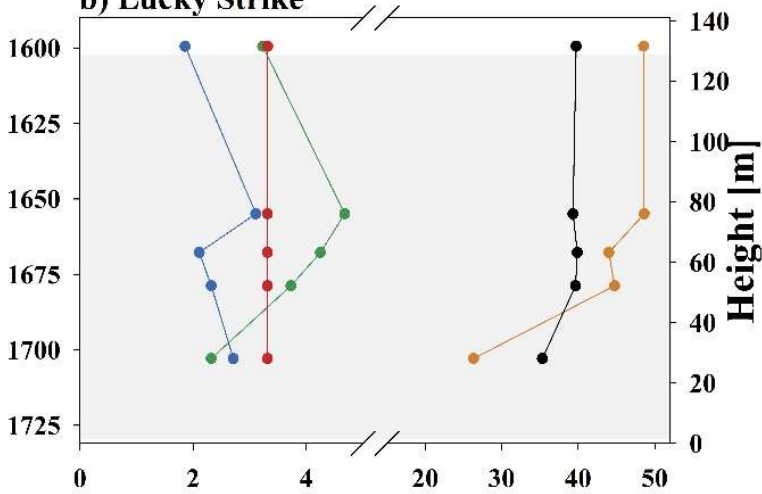

d) Lost City

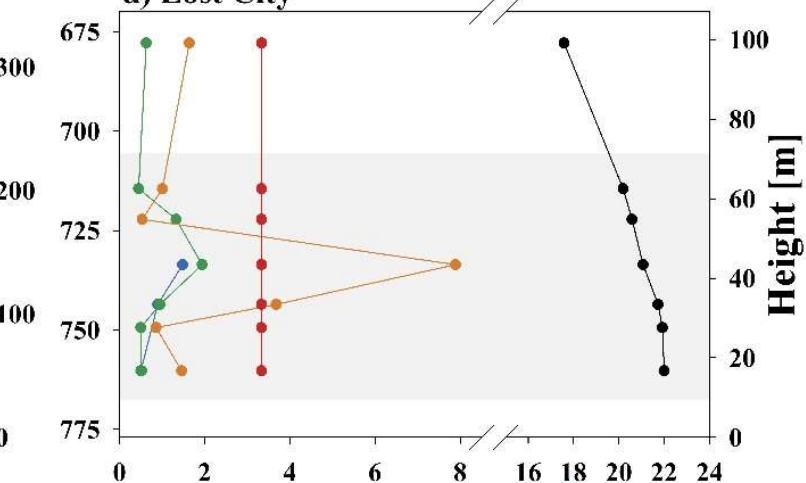

f) TAG

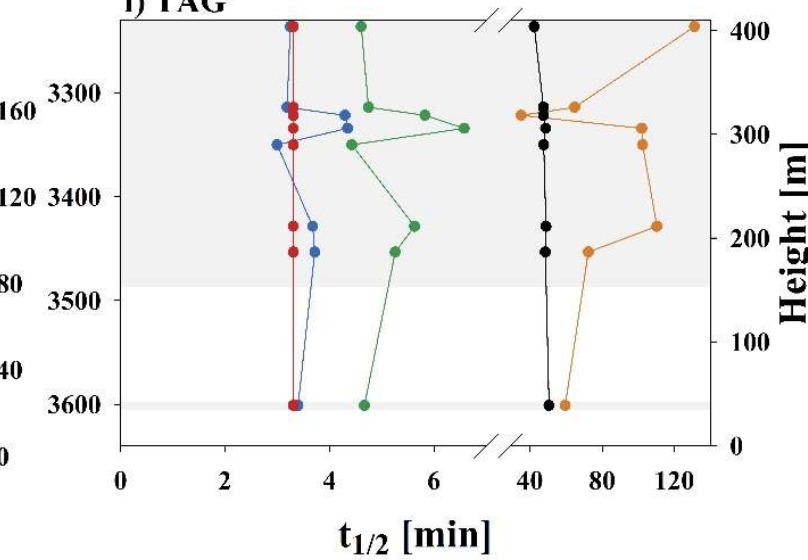

595 Figure 4. The measured Fe(II) half-life ( $\mathrm{t}_{1 / 2}$, min) at $\mathrm{T}_{\text {is }} \mathrm{pH}_{\text {is }}$ (orange), $\mathrm{T}_{25} \mathrm{pH}_{\text {is }}$ (green), and

$596 \mathrm{~T}_{25} \mathrm{pH}_{8}$ (blue), and the theoretical (Theo) values for $\mathrm{T}_{i s} \mathrm{pH}_{\text {is }}$ (black), and $\mathrm{T}_{25} \mathrm{pH}_{8}$ (red), at the

597 six vents. The shaded area shows the anomaly depths determined using light scattering data .

598 Both, the depth (left y-axis) and the height above the seafloor (right y-axis) of the sampling

599 are indicated. 
a) $\mathrm{T}_{\text {is }} \mathrm{pH}_{\text {is }}$

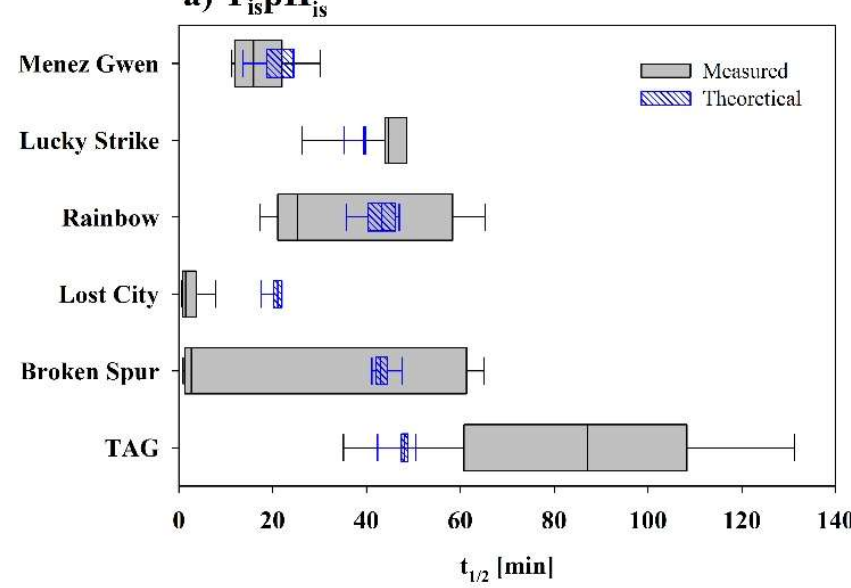

b) $\mathrm{T}_{25} \mathrm{pH}_{8}$

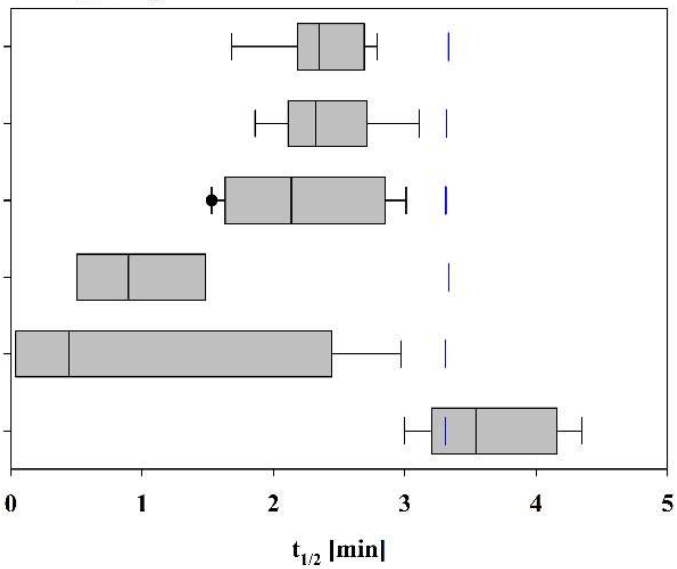

601 Figure 5. Boxplots of the Fe(II) half-life $\left(\mathrm{t}_{1 / 2}, \mathrm{~min}\right)$ within the six hydrothermal plumes. a)

602 The measured $\mathrm{t}_{1 / 2}$ at in situ conditions (grey) and the theoretical $\mathrm{t}_{1 / 2}$ (blue; obtained using Eq.

603 4). b) The measured $\mathrm{t}_{1 / 2}$ at constant temperature $\left(25^{\circ} \mathrm{C}\right)$ and $\mathrm{pH} 8$ (grey) and the

604 corresponding theoretical $\mathrm{t}_{1 / 2}$, the slight variances are caused by $\mathrm{S}$ changes (blue).

a) Rainbow $\mathrm{T}_{\text {is }} \mathbf{p} \mathrm{H}_{\text {is }}$

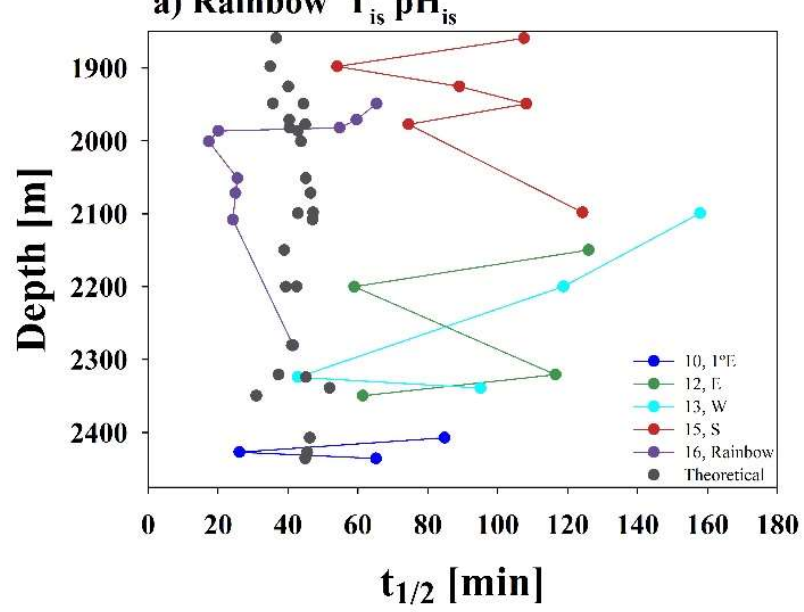

b) Rainbow $\mathrm{T}_{25} \mathrm{pH}_{8}$

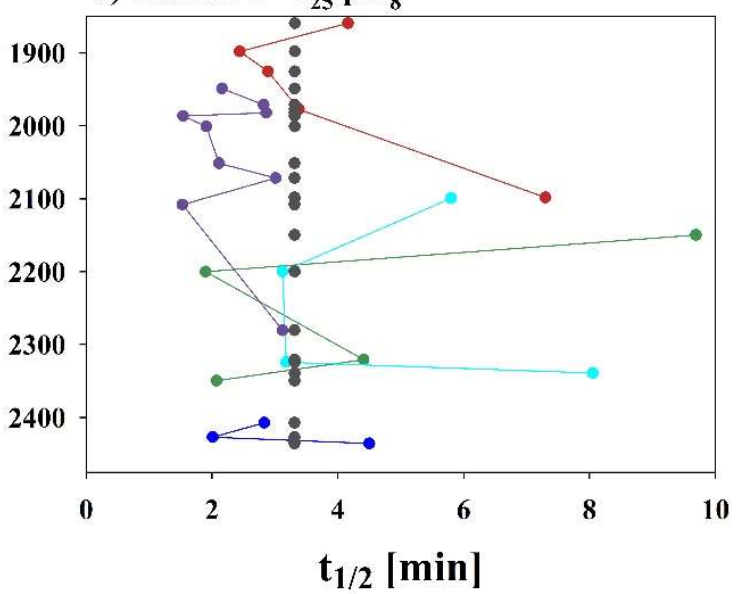

606 Figure 6. The Fe(II) half-life ( $\left.\mathrm{t}_{1 / 2}, \mathrm{~min}\right)$ at the Rainbow field a) under in situ conditions (see

607 also Supplementary Table S1) and b) normalized to constant $\mathrm{T}$ of $25^{\circ} \mathrm{C}$ and a $\mathrm{pH}$ of 8 . 
a) TAG $\mathrm{T}_{\text {is }} \mathrm{pH}_{\text {is }}$

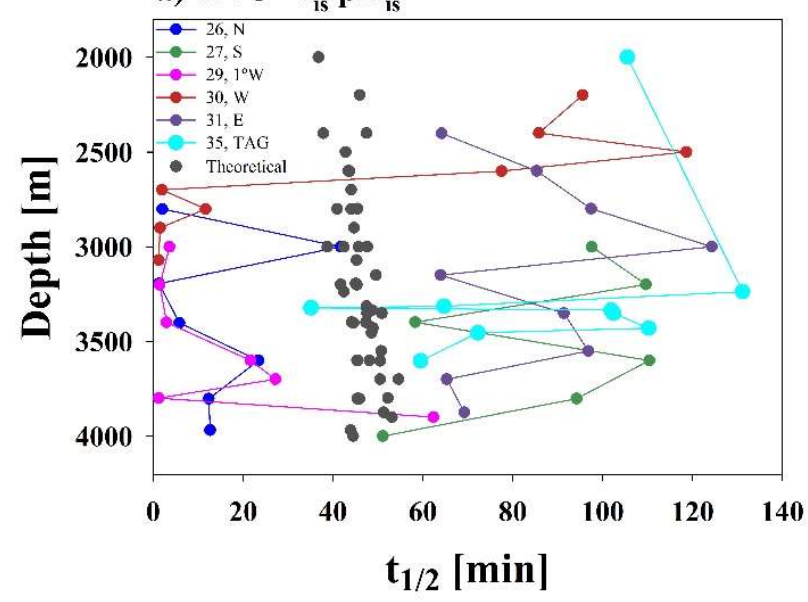

b) TAG $\mathrm{T}_{25} \mathrm{pH}_{8}$

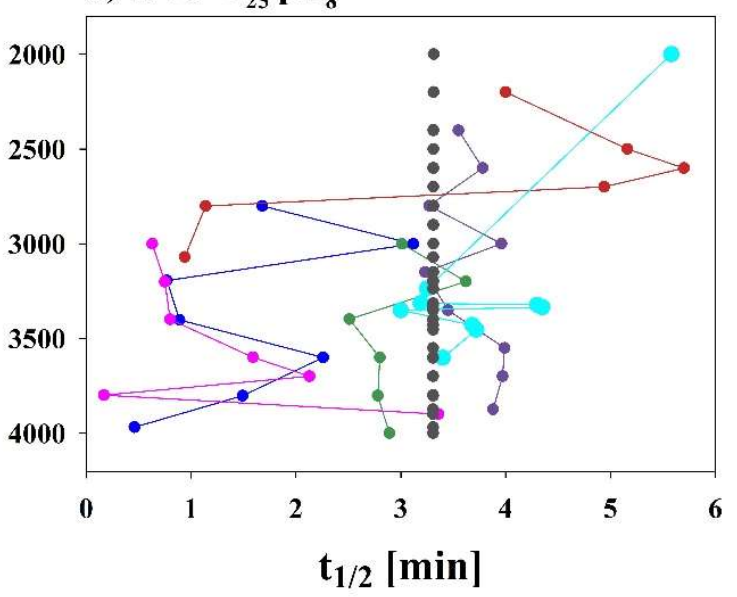

609 Figure 7. The Fe(II) half-life $\left(\mathrm{t}_{1 / 2}, \mathrm{~min}\right)$ at the TAG field a) under in situ conditions (see also

610 Supplementary Table S1) and b) normalized to constant $\mathrm{T}$ of $25^{\circ} \mathrm{C}$ and a $\mathrm{pH}$ of 8 .
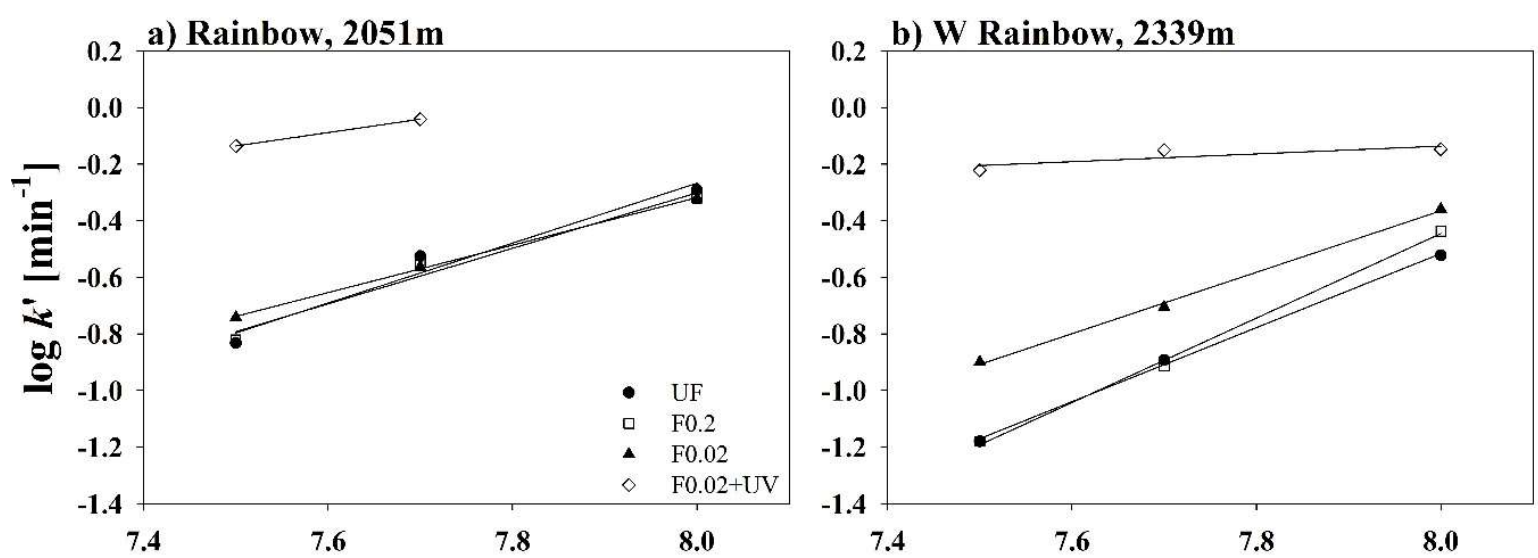

c) Broken Spur, $2829 \mathrm{~m}$
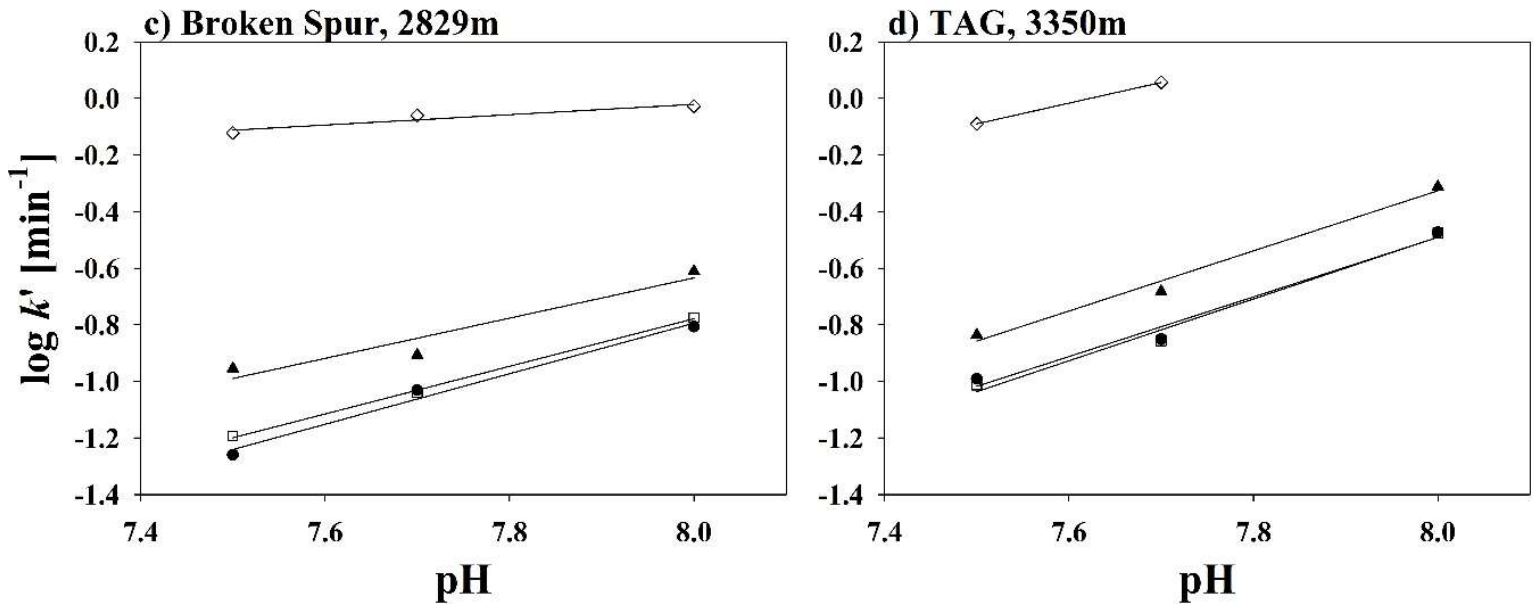

611

612 Figure 8. Oxidation rate constants at different $\mathrm{pH}(7.5,7.7$ and 8), for selected unfiltered (UF,

613 filled circles), filtered through $0.2 \mu \mathrm{m}$ (F0.2, open squares), filtered through $0.02 \mu \mathrm{m}$ (F0.02, 
614 filled triangles) and filtered through $0.02 \mu \mathrm{m}$ followed by UV irradiation (F0.02+UV, open

615 diamonds) samples at a) Rainbow (Stn 16, $2051 \mathrm{~m})$, b) West of Rainbow (Stn 13, $2339 \mathrm{~m}), \mathrm{c})$

616 Broken Spur (Stn 24, $2829 \mathrm{~m})$ and d) TAG (Stn 35, $3350 \mathrm{~m})$.

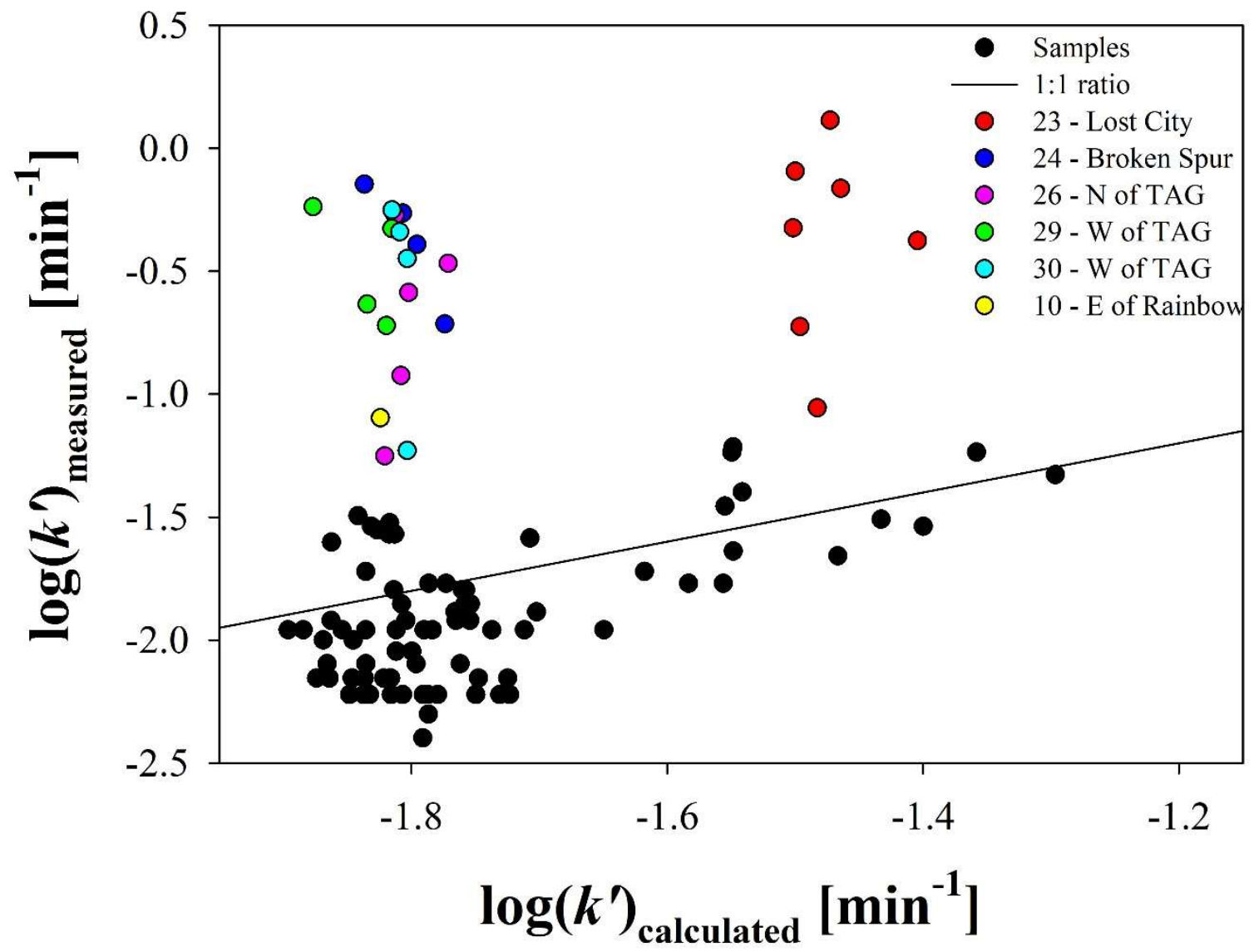

617

618 Figure 9. Fe(II) oxidation rate constants $\left(\log \left(k^{\prime}\right)\right)$ determined under in situ conditions against

619 the anticipated expected theoretical value. All data points are shown in black. The black line

620 represents a 1:1 ratio between both oxidation rate constants. Color coded data points

621 correspond to samples with measured oxidation rate constants greater than $20 \%$ of the

622 theoretically derived rate constants. 
624 DGS wrote the manuscript with significant contributions from all coauthors. DGS was 625 invited to the research cruise by MCL and AT, where DGS, MCL, and LA collected the 626 samples. DGS analyzed the samples with support from MSC and MGD. Figures for the 627 results were designed by HP and GS. Fieldwork logistics and costs were overseen by MCL 628 and AT, while analysis costs were handled by MSC, MGD, GS, and HP.

\section{Acknowledgements}

630 The authors would like to thank the captain and crew of the R.R.S. James Cook as well as the 631 scientific team during the GA13 cruise. The field work was supported by NERC 632 (NE/N010396/1 and NE/N009525/1) awards to AT and MCL. This work was supported by 633 ISblue project, Interdisciplinary graduate school for the blue planet (ANR-17-EURE-0015) 634 and co-funded by a grant from the French government under the program "Investissements 635 d'Avenir". Lab work was supported by the ATOPFe CTM2017-83476-P project (Spanish 636 Ministry of Economy and Competitiveness) awarded to MSC and MGD.

\section{Competing interests}

638 The authors declare no competing interests.

\section{References}

640 Andreani M., Escartin J., Delacour A., Ildefonse B., Godard M., Dyment J., Fallick A. E. and 641 Fouquet Y. (2014) Tectonic structure, lithology, and hydrothermal signature of the Rainbow massif (Mid-Atlantic Ridge $36^{\circ} 14^{\prime} \mathrm{N}$ ). Geochemistry, Geophys. Geosystems

644 Armstrong R. A., Lee C., Hedges J. I., Honjo S. and Wakeham S. G. (2001) A new, mechanistic model for organic carbon fluxes in the ocean based on the quantitative 
646

647

648

649

650

651

652

653

654

655

656

657

658

659

660

661

662

663

664

665

666

667

de Baar H. J. W. and De Jong J. T. M. (2001) Distributions, sources and sinks of iron in seawater. In The Biogeochemistry of Iron in Seawater (eds. D. Turner and K. A. Hunter). John Wiley \& Sons Ltd., Chichester, UK. pp. 125-253.

Bennett S. A., Achterberg E. P., Connelly D. P., Statham P. J., Fones G. R. and German C. R. (2008) The distribution and stabilisation of dissolved Fe in deep-sea hydrothermal plumes. Earth Planet. Sci. Lett. 270, 157-167.

Buck K. N., Sohst B. and Sedwick P. N. (2015) The organic complexation of dissolved iron along the U.S. GEOTRACES (GA03) North Atlantic Section. Deep Sea Res. Part II Top. Stud. Oceanogr. 116, 152-165.

Bundy R. M., Biller D. V, Buck K. N., Bruland K. W. and Barbeau K. A. (2014) Distinct pools of dissolved iron-binding ligands in the surface and benthic boundary layer of the California Current. Limnol. Oceanogr. 59, 769-787.

Charlou J. L., Donval J. P., Douville E., Jean-Baptiste P., Radford-Knoery J., Fouquet Y., Dapoigny A. and Stievenard M. (2000) Compared geochemical signatures and the evolution of Menez Gwen $\left(35^{\circ} 50 \mathrm{~N}\right)$ and Lucky Strike $\left(37^{\circ} 17 \mathrm{~N}\right)$ hydrothermal fluids, south of the Azores Triple Junction on the Mid-Atlantic Ridge. Chem. Geol. 171, 49-75.

Chin C. S., Coale K. H., Elrod V. A., Johnson K. S., Massoth G. J. and Baker E. T. (1994) In situ observations of dissolved iron and manganese in hydrothermal vent plumes, Juan de Fuca Ridge. J. Geophys. Res. Solid Earth 99, 4969-4984.

Conway T. J. and John S. G. (2014) Quantification of dissolved iron sources to the North 
669

670

671

672

673

674

675

676

677

678

679

680

681

682

683

684

685

686

687

688

689

Douville E., Charlou J. L., Oelkers E. H., Bienvenu P., Jove Colon C. F., Donval J. P., Fouquet Y., Prieur D. and Appriou P. (2002) The rainbow vent fluids (36² $\left.14^{\prime} \mathrm{N}, \mathrm{MAR}\right)$ : The influence of ultramafic rocks and phase separation on trace metal content in MidAtlantic Ridge hydrothermal fluids. Chem. Geol. 184, 37-48.

Elderfield H. and Schultz A. (1996) Mid-ocean ridge hydrothermal fluxes and the chemical composition of the ocean. Annu. Rev. Earth Planet. Sci. 24, 191-224.

Field M. P. and Sherrell R. M. (2000) Dissolved and particulate Fe in a hydrothermal plume at $9^{\circ} 45^{\prime} \mathrm{N}$, East Pacific Rise: Slow Fe (II) oxidation kinetics in Pacific plumes. Geochim. Cosmochim. Acta 64, 619-628.

Fitzsimmons J. N., John S. G., Marsay C. M., Hoffman C. L., Nicholas S. L., Toner B. M., German C. R. and Sherrell R. M. (2017) Iron persistence in a distal hydrothermal plume supported by dissolved-particulate exchange. Nat. Geosci. 10, 195-201.

Fouquet Y., Cambon P., Etoubleau J., Charlou J. L., Ondréas H., Barriga F. J. A. S., Cherkashov G., Semkova T., Poroshina I., Bohn M., Donval J. P., Henry K., Murphy P. and Rouxel O. (2013) Geodiversity of hydrothermal processes along the mid-atlantic ridge and ultramafic-hosted mineralization: A new type of oceanic $\mathrm{Cu}-\mathrm{Zn}-\mathrm{Co}-\mathrm{Au}$ volcanogenic massive sulfide deposit. Geophys. Monogr. Ser. 188, 321-367.

Gamo T., Chiba H., Masuda H., Edmonds H. N., Fujioka K., Kodama Y., Nanba H. and Sano Y. (1996) Chemical characteristics of hydrothermal fluids from the TAG Mound of the Mid-Atlantic Ridge in August 1994: Implications for spatial and temporal variability of hydrothermal activity. Geophys. Res. Lett. 23, 3483-3486. 
690 Gartman A. and Findlay A. J. (2020) Impacts of hydrothermal plume processes on oceanic metal cycles and transport. Nat. Geosci. 13, 396-402.

692

German C. R. and Von Damm K. L. (2004) Hydrothermal processes. In The Oceans and

693 Marine Geochemistry (eds. H. D. Holland, K. K. Turekian, and H. Elderfield). Elsevier694 Pergamon. pp. 181-222.

Gledhill M. and Buck K. (2012) The Organic Complexation of Iron in the Marine Environment: A Review. Front. Microbiol. 3, 69.

González-Davila M., Santana-Casiano J. M. and Millero F. J. (2005) Oxidation of iron (II) nanomolar with $\mathrm{H}_{2} \mathrm{O}_{2}$ in seawater. Geochim. Cosmochim. Acta 69, 83-93.

González-Dávila M., Santana-Casiano J. M. and Millero F. J. (2006) Competition between $\mathrm{O}_{2}$ and $\mathrm{H}_{2} \mathrm{O}_{2}$ in the oxidation of $\mathrm{Fe}$ (II) in natural waters. J. Solution Chem. 35, 95-111.

Gray S. E. C., DeGrandpre M. D., Moore T. S., Martz T. R., Friederich G. E. and Johnson K. S. (2011) Applications of in situ pH measurements for inorganic carbon calculations.

Hawkes J. A., Hansen C. T., Goldhammer T., Bach W. and Dittmar T. (2016) Molecular Mar. Chem. 125, 82-90. alteration of marine dissolved organic matter under experimental hydrothermal conditions. Geochim. Cosmochim. Acta 175, 68-85.

Hong H. and Kester D. R. (1986) Redox state of iron in the offshore waters of Peru ${ }^{1}$. Limnol. Oceanogr. 31, 512-524. $651-659$. 
Kelley D. S., Karson J. A., Blackman D. K., Früh-Green G. L., Butterfield D. A., Lilley M. D., Olson E. J., Schrenk M. O., Roe K. K. and Lebon G. T. (2001) An off-axis hydrothermal vent field near the Mid-Atlantic Ridge at 30 N. Nature 412, 145-149.

Key R. M., Olsen A., van Heuven S., Lauvset S. K., Velo A., Lin X., Schirnick C., Kozyr A., Tanhua T. and Hoppema M. (2015) Global ocean data analysis project, version 2 (GLODAPv2).

King D. W. (1998) Role of carbonate speciation on the oxidation rate of Fe (II) in aquatic systems. Environ. Sci. Technol. 32, 2997-3003.

King D. W., Lounsbury H. A. and Millero F. J. (1995) Rates and Mechanism of Fe(II) Oxidation at Nanomolar Total Iron Concentrations. Environ. Sci. Technol. 29, 818-824.

Lough A. J. M., Homoky W. B., Connelly D. P., Comer-Warner S. A., Nakamura K., Abyaneh M. K., Kaulich B. and Mills R. A. (2019) Soluble iron conservation and colloidal iron dynamics in a hydrothermal plume. Chem. Geol. 511, 225-237.

Ludwig K. A., Kelley D. S., Butterfield D. A., Nelson B. K. and Früh-Green G. L. (2006) Formation and evolution of carbonate chimneys at the Lost City Hydrothermal Field. Geochim. Cosmochim. Acta 70, 3625-3645.

Lueker T. J., Dickson A. G. and Keeling C. D. (2000) Ocean $\mathrm{pCO}_{2}$ calculated from dissolved inorganic carbon, alkalinity, and equations for $\mathrm{K}_{1}$ and $\mathrm{K}_{2}$ : validation based on laboratory measurements of $\mathrm{CO}_{2}$ in gas and seawater at equilibrium. Mar. Chem. 70, 105-119.

Mandernack K. W. and Tebo B. M. (1993) Manganese scavenging and oxidation at hydrothermal vents and in vent plumes. Geochim. Cosmochim. Acta 57, 3907-3923.

Massoth G. J., Baker E. T., Feely R. A., Lupton J. E., Collier R. W., Gendron J. F., Roe K. 

K., Maenner S. M. and Resing J. A. (1998) Manganese and iron in hydrothermal plumes resulting from the 1996 Gorda Ridge Event. Deep Sea Res. Part II Top. Stud. Oceanogr. 45, 2683-2712.

Massoth G. J., Baker E. T., Lupton J. E., Feely R. A., Butterfield D. A., Von Damm K. L., Roe K. K. and Lebon G. T. (1994) Temporal and spatial variability of hydrothermal manganese and iron at Cleft segment, Juan de Fuca Ridge. J. Geophys. Res. Solid Earth 99, 4905-4923.

Millero F. J. (1986) The pH of estuarine waters. Limnol. Oceanogr. 31, 839-847.

Millero F. J. and Sotolongo S. (1989) The oxidation of Fe (II) with $\mathrm{H}_{2} \mathrm{O}_{2}$ in seawater. Geochim. Cosmochim. Acta 53, 1867-1873.

Millero F. J., Sotolongo S. and Izaguirre M. (1987) The oxidation kinetics of Fe(II) in seawater. Geochim. Cosmochim. Acta 51, 793-801.

Millero F. J., Yao W. and Aicher J. (1995) The speciation of Fe (II) and Fe (III) in natural waters. Mar. Chem. 50, 21-39.

Moore C. M., Mills M. M., Arrigo K. R., Berman-Frank I., Bopp L., Boyd P. W., Galbraith E. D., Geider R. J., Guieu C., Jaccard S. L., Jickells T. D., La Roche J., Lenton T. M., Mahowald N. M., Marañón E., Marinov I., Moore J. K., Nakatsuka T., Oschlies A., Saito M. A., Thingstad T. F., Tsuda A. and Ulloa O. (2013) Processes and patterns of oceanic nutrient limitation. Nat. Geosci. 6, 701-710.

Morel F. M. M., Kustka A. B. and Shaked Y. (2008) The role of unchelated Fe in the iron nutrition of phytoplankton. Limnol. Oceanogr. 53, 400-404.

Moriceau B., Goutx M., Guigue C., Lee C., Armstrong R., Duflos M., Tamburini C., 
Charrière B. and Ragueneau O. (2009) Si-C interactions during degradation of the diatom Skeletonema marinoi. Deep Sea Res. Part II Top. Stud. Oceanogr. 56, 13811395.

Mottl M. J., Holland H. D. and Corr R. F. (1979) Chemical exchange during hydrothermal alteration of basalt by seawater-II. Experimental results for Fe, Mn, and sulfur species. Geochim. Cosmochim. Acta 43, 869-884.

762

O’Sullivan D. W., Neale P. J., Coffin R. B., Boyd T. J. and Osburn C. L. (2005) Photochemical production of hydrogen peroxide and methylhydroperoxide in coastal

Olsen A., Key R. M., Van Heuven S., Lauvset S. K., Velo A., Lin X., Schirnick C., Kozyr A., waters. Mar. Chem. 97, 14-33.

Resing J. A., Sedwick P. N., German C. R., Jenkins W. J., Moffett J. W., Sohst B. M. and Tanhua T. and Hoppema M. (2016) The Global Ocean Data Analysis Project version 2 (GLODAPv2)-an internally consistent data product for the world ocean. Earth Syst. Sci.

Rose A. L. and Waite T. D. (2003) Effect of dissolved natural organic matter on the kinetics of ferrous iron oxygenation in seawater. Environ. Sci. Technol. 37, 4877-4886.

Rouxel O., Toner B., Germain Y. and Glazer B. (2018) Geochemical and iron isotopic insights into hydrothermal iron oxyhydroxide deposit formation at Loihi Seamount. Geochim. Cosmochim. Acta 220, 449-482.

Roy E. G. and Wells M. L. (2011) Evidence for regulation of Fe (II) oxidation by organic 
Roy E. G., Wells M. L. and King D. W. (2008) Persistence of iron (II) in surface waters of the western subarctic Pacific. Limnol. Oceanogr. 53, 89-98.

Rudnicki M. D. and Elderfield H. (1993) A chemical model of the buoyant and neutrally buoyant plume above the TAG vent field, 26 degrees N, Mid-Atlantic Ridge. Geochim. Cosmochim. Acta 57, 2939-2957.

Rue E. L. and Bruland K. W. (1995) Complexation of iron(III) by natural organic ligands in the Central North Pacific as determined by a new competitive ligand equilibration/adsorptive cathodic stripping voltammetric method. Mar. Chem. 50, 117138.

Santana-Casiano J. M., González-Dávila M., González A. G. and Millero F. J. (2010) Fe (III) reduction in the presence of catechol in seawater. Aquat. geochemistry 16, 467-482.

Santana-Casiano J. M., González-Dávila M. and Millero F. J. (2005) Oxidation of nanomolar level of Fe(II) with oxygen in natural waters. Environ. Sci. Technol. 39, 2073-2079.

Santana-Casiano J. M., González-Dávila M. and Millero F. J. (2006) The role of Fe(II) species on the oxidation of $\mathrm{Fe}(\mathrm{II})$ in natural waters in the presence of $\mathrm{O}_{2}$ and $\mathrm{H}_{2} \mathrm{O}_{2}$. Mar. Chem. 99, 70-82.

Santana-Casiano J. M., González-Dávila M., Rodríguez M. J. and Millero F. J. (2000) The effect of organic compounds in the oxidation kinetics of Fe(II). Mar. Chem. 70, 211222.

Santana-González C., González-Dávila M., Santana-Casiano J. M., Gladyshev S. and Sokov A. (2019) Organic matter effect on Fe (II) oxidation kinetics in the Labrador Sea. Chem. 
801

802

803

804

805

806

807

808

809

810

811

812

\section{3}

Santana-González C., Santana-Casiano J. M., González-Dávila M. and Fraile-Nuez E. (2017) Emissions of $\mathrm{Fe}(\mathrm{II})$ and its kinetic of oxidation at Tagoro submarine volcano, El Hierro. Mar. Chem. 195, 129-137.

Santana-González C., Santana-Casiano J. M., González-Dávila M., Santana-del Pino A., Gladyshev S. and Sokov A. (2018) Fe (II) oxidation kinetics in the North Atlantic along the $59.5^{\circ} \mathrm{N}$ during 2016. Mar. Chem. 203, 64-77.

Searle R. (2013) Mid-ocean ridges., Cambridge University Press.

Shaked Y., Kustka A. B. and Morel F. M. M. (2005) A general kinetic model for iron acquisition by eukaryotic phytoplankton. Limnol. Oceanogr. 50, 872-882.

Statham P. J., German C. R. and Connelly D. P. (2005) Iron (II) distribution and oxidation kinetics in hydrothermal plumes at the Kairei and Edmond vent sites, Indian Ocean. Earth Planet. Sci. Lett. 236, 588-596.

Stumm W. and Lee G. F. (1961) Oxygenation of ferrous iron. Ind. Eng. Chem. 53, 143-146.

Tagliabue A., Bopp L., Dutay J. C., Bowie A. R., Chever F., Jean-Baptiste P., Bucciarelli E., Lannuzel D., Remenyi T., Sarthou G., Aumont O., Gehlen M. and Jeandel C. (2010) Hydrothermal contribution to the oceanic dissolved iron inventory. Nat. Geosci. 3, 252256.

Tagliabue A., Bowie A. R., Boyd P. W., Buck K. N., Johnson K. S. and Saito M. A. (2017) The integral role of iron in ocean biogeochemistry. Nature 543, 51-59.

Tagliabue A. and Völker C. (2011) Towards accounting for dissolved iron speciation in 
822 Ussher S. J., Achterberg E. P. and Worsfold P. J. (2004) Marine biogeochemistry of iron. $823 \quad$ Environ. Chem. 1, 67-80.

824 Voelker B. M. and Sedlak D. L. (1995) Iron reduction by photoproduced superoxide in 825 seawater. Mar. Chem. 50, 93-102.

826 Voelker B. M. and Sulzberger B. (1996) Effects of fulvic acid on Fe (II) oxidation by 827 hydrogen peroxide. Environ. Sci. Technol. 30, 1106-1114.

828 Wang H., Yang Q., Ji F., Lilley M. D. and Zhou H. (2012) The geochemical characteristics 829 and Fe (II) oxidation kinetics of hydrothermal plumes at the Southwest Indian Ridge. $830 \quad$ Mar. Chem. 134, 29-35.

831 Yuan J. and Shiller A. M. (2001) The distribution of hydrogen peroxide in the southern and 832 central Atlantic ocean. Deep Sea Res. Part II Top. Stud. Oceanogr. 48, 2947-2970.

833 Yücel M., Gartman A., Chan C. S. and Luther G. W. (2011) Hydrothermal vents as a 834 kinetically stable source of iron-sulphide-bearing nanoparticles to the ocean., Nature $835 \quad$ Publishing Group. 